\title{
АРМЯНЕ РОССИИ - ГЕОДЕМОГРАФИЧЕСКИЕ ТЕНДЕНЦИИ ПРОШЛОГО, СОВРЕМЕННЫЕ РЕАЛИИ И ПЕРСПЕКТИВЫ
}

\section{СЕРГЕЙ СУщИй}

\begin{abstract}
В статье анализируется количественный рост, пространственная динамика, гендерная структура и форма расселения армянского населения России в XVIII-XX веках. Изучено демографическое соотношение крупнейших региональных сообществ на разных этапах их развития. Определень основные исторические периоды геодемографической динамики армян России.
\end{abstract}

\begin{abstract}
Первый может быть обозначен как «южнороссийский» (вторая треть XVIII века - 1920-е годы). На его протяжении подавляющая часть армянского населения России концентрировалась в пределах южного макрорегиона. На втором этапе (середина 1920-х - первая половина 1980-х г2.) армяне расселяются почти по всей территории РСФСР, но представляют внутренне слабосвязанные этнические группы. Третий период (вторая половина 1980-х - настоящее время) связан с трансформащией данных групп в развитые региональные общины.
\end{abstract}

Три века количественного роста позволили армянам стать к началу ХХІ века одним из крупнейших народов Российской Федерации. В среднесрочной перспективе (к 2030 г.) при благоприятном сиенарии демографической динамики армяне в состоянии занять третью позицию 6 демографическом рейтинге народов России (следом за русскими и татарами).

Ключевые слова: геодемографическая динамика, армянское население России, региональные диаспоры, миграџионные процессы, система расселения, гендерный баланс.

Учитывая исторически изменчивую динамику территориальных пределов Российского государства, геодемографическая динамика армянского населения будет рассматриваться нами в пространственных границах современной Российской Федерации (по состоянию на 2018 г.). Тем самым мы исключаем из данного исследования анализ крупных средоточий армян, существовавших не только в пределах Армянской или двух других закавказских, но и всех остальных союзных республик бывшего СССР, как и ряда регионов, до 1917 г. входивших в состав Российской империи. Но в отдельных случаях (они оговариваются в тексте) речь будет идти обо всем армянском населении страны, будь то Российская империя или Советский Союз. При этом под Югом России (южным макрорегионом) мы будем понимать районы Подонья, нижнего Поволжья, степного Предкавказья, Северного Кавказа и Крыма, т.е. территории, в настоящее время составляющие два федеральных округа Южный и Северо-Кавказский.

СЕРГЕЙ ЯКОВЛЕВИЧ СУЩИЙ (SS7707@mail.ru), ФЕДЕРАЛЬНЫЙ ИССЛЕДОВАТЕЛЬСКИЙ ЦЕНТР ЮЖНЫЙ НАУЧНЫЙ ЦЕНТР РАН, РОССИЯ.

РАБОТА ВЫПОЛНЕНА В РАМКАХ ПРОЕКТА РФФИ «АРМЯНСКАЯ ОБЩИНА ДОНА В НОВЕЙШИЙ ПЕРИОД: ИСТОРИЯ, ИНСТИТУТЫ, ИДЕНТИЧНОСТЬ» (18-59-05004).

СТАТЬЯ ПОСТУПИЛА В РЕДАКЦИЮ В МАЕ 2018 Г. 
Отдельные выходцы из Армении или локальные группы ее уроженцев появляются в пределах будущей России еще в античности и средневековье. Но только с момента включения в состав Российского государства нижнего Поволжья (середина XVI века) в пределах страны появляются центры с крупными армянскими общинами (прежде всего выделим Астрахань, в которой армяне являлись старожильческим населением). Число таких центров заметно увеличивается в XVIII веке, когда на присоединенных землях степного Предкавказья начинает формироваться новый российский макрорегион.

Организованные (или стимулируемые) властью миграции армянского населения закладывают в это время основы его поселенческой сети в пределах Юга России. Основные ее средоточия со второй половины столетия становятся центрами притяжения и концентрации все новых групп переселенцев. Самым существенным образом меняется и удельная композиция очагов армянского присутствия в южном макрорегионе. Если в XVIXVII веках основные средоточия армян - это Астрахань, Дербент, адыго-черкеский ареал черкесогаев на Северо-Западном Кавказе, то в середине - второй половине XVIII века на значимые позиции выдвигаются нижнее Подонье (Нор-Нахичеван с прилегающими армянскими селами), Кизлярский и Моздокский уезды Кавказской области. В общей сложности армянское население Юга России на рубеже XIX века составляет порядка 23-24 тыс. человек (без черкесогаев, учет которых способен увеличить данное множество до 30 35 тыс.). На южный макрорегион приходится до 98-99\% армянского населения всей России, и он на долгое время становится основным их средоточием (рисунок 1).

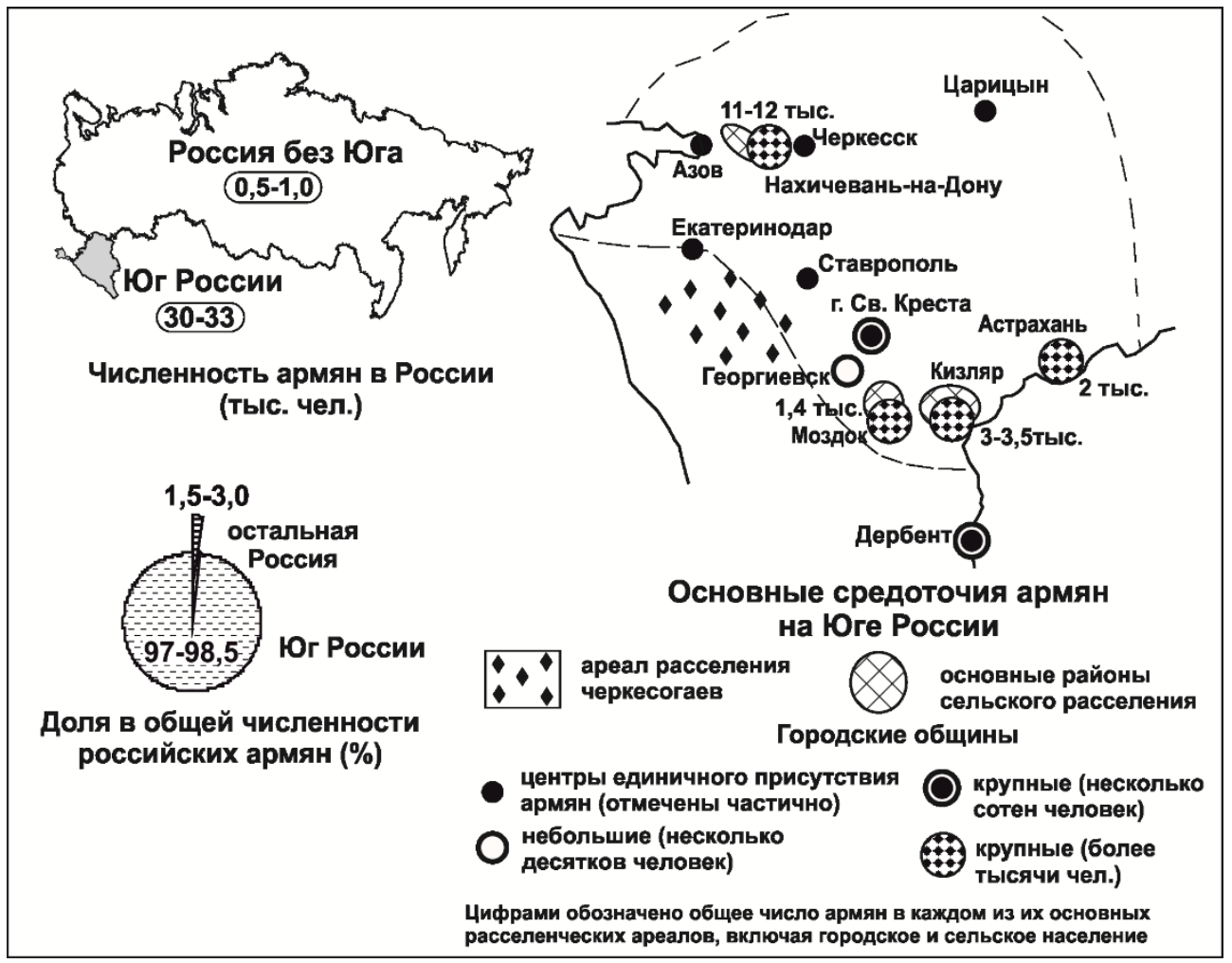

Рисунок 1. Армяне в России, 1800 1

\footnotetext{
${ }^{1}$ Для составления картосхемы использовались данные взятые из [Аваков 2012; Аганесова, Суздальцева
} 2007; Акопян 2005; Аракелян 1984; Волкова 1966; Кабузан 1990, 1996; Тер-Саркисянц 1998, 2005$].$ 
Даже спустя 100 лет, в конце XIX века, система расселения армян в пределах большой России почти не изменилась, при том что в составе империи появилось Закавказье, располагавшее многочисленным армянским населением. Но территории данного национального региона армяне практически не покидали. За его пределами их было немного, и они по-прежнему в максимальной степени концентрировались в Новороссии, которая в это время помимо степного Предкавказья (Дон, Кубань и Ставрополье) включала причерноморские губернии и Бессарабию. Как результат на Юг России все еще приходилось более 95\% армянского населения, расселенного в территориальных границах современной РФ (рисунок 2).

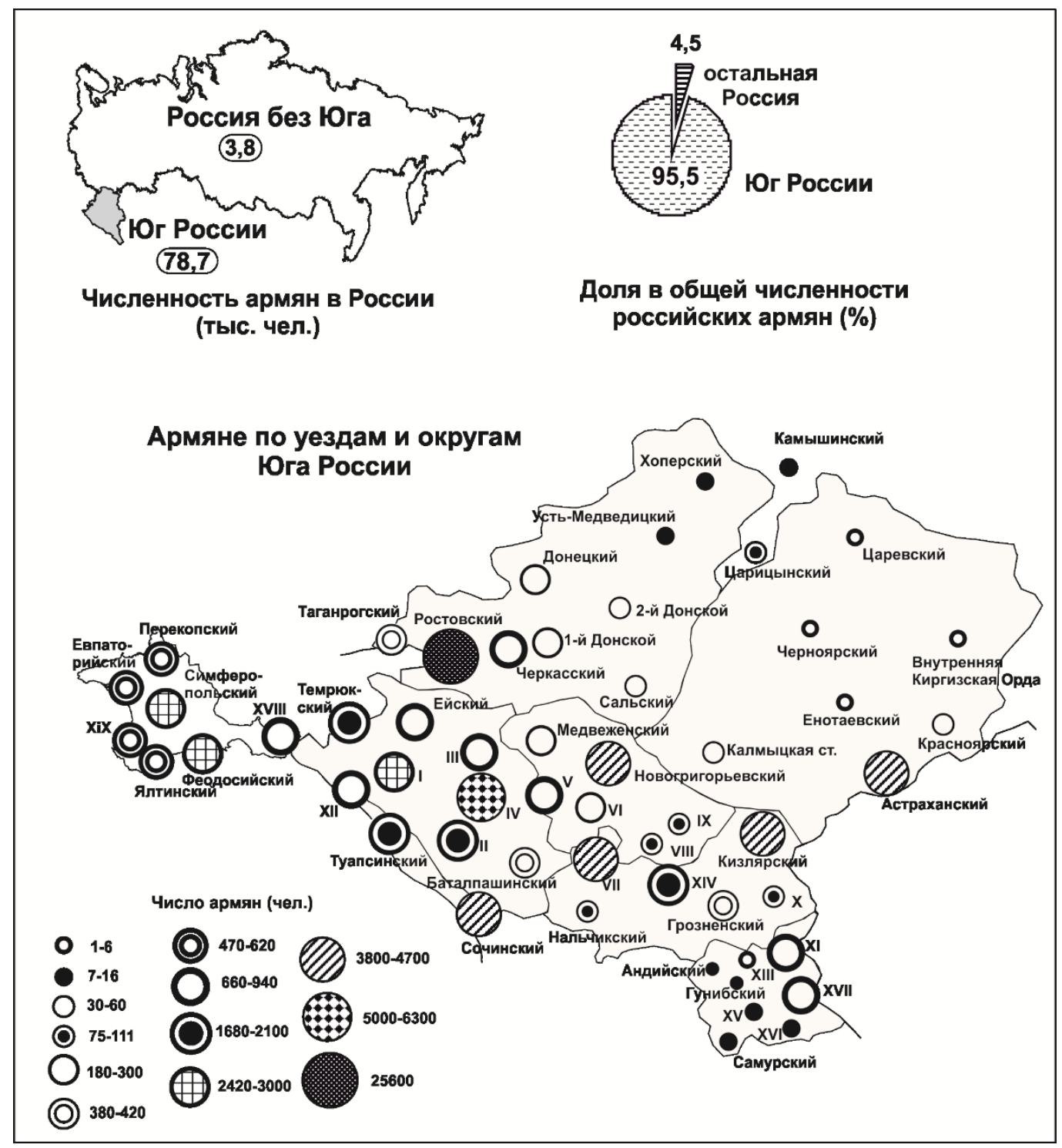

Рисунок 2. Армяне в России, $1897^{2}$

\footnotetext{
2 Для составления картосхем 2-3, 5-17 использовались материалы Первой всеобщей переписи населения Российской империи 1897 г., а также Всесоюзных переписей населения 1926-1989 гг. и Всероссийских переписей населения 2002-2010 гг. Геодемографическая статистика армянского населения на 2002 и 2010 гг. по российским регионам и городским центрам была собрана с сайта Росстата, а также, частично, с сайтов его региональных отделений. Электронные ресурсы: перепись 1897 г. - URL: http://demoscope.ru/weekly/ssp/emp_lan_97_uezd.php; перепись 1926 г. - URL:
} 
В подавляющем большинстве губерний центральной, северной или зауральской России армяне на рубеже XIX-XX веков крайне малочисленны. Первая всеобщая перепись населения империи 1897 г. зафиксировала их здесь по 5-15 человек на губернию. Эти малые группы отличал очень высокий по меркам данного времени уровень урбанизации и преимущественно мужской состав. В большинстве губерний империи число армян-мужчин в 3-4 раза (иногда и в 10-12 раз) превышало число женщин. Учитывая минимальные размеры и гендерный дисбаланс, речь скорее идет даже не о локальных этнических группах, но о дисперсном расселении - некотором числе одиноких мужчин, проживающих в городах, причем преимущественно крупных, уровня губернского центра.

Среди демографических средоточий армянского населения в пределах центральной России выделим обе столичных общины (рисунок 3). Впрочем, и они по своему размеру на рубеже XX века в разы уступают городским армянским общинам многих южнороссийских городов (а петербургская вообще не попадает в первую десятку).

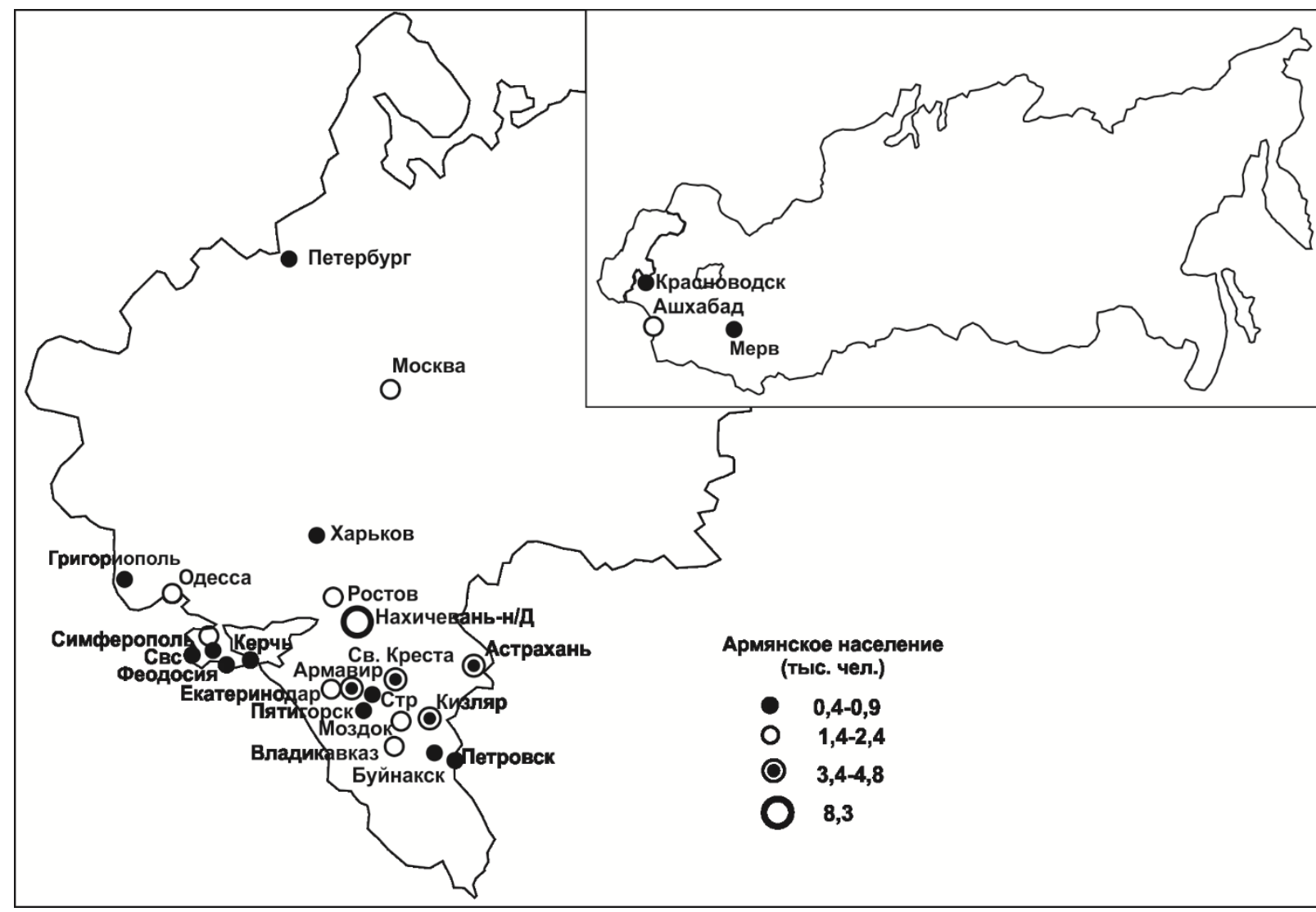

Рисунок 3. Крупнейшие городские общины армян в Российской империи, 1897 г. (без Закавказья)

http://demoscope.ru/weekly/ssp/rus_nac_26.php?reg; перепись 1939 г. - URL:

http://demoscope.ru/weekly/ssp/rus_nac_39.php; перепись 1959 г. - URL: http://demoscope.ru/weekly /ssp/rus_nac_59.php; перепись 1970 г.-URL: http://demoscope.ru/weekly/ssp/rus_nac_70.php; перепись 1979 г. - URL: http://demoscope.ru/weekly/ssp/rus_nac_79.php; перепись 1989 г. - URL: http://demoscope.ru /weekly/ssp/rus_nac_89.php; перепись 2002 г. - URL: http://demoscope.ru/weekly/ssp/rus_nac_02.php; перепись 2010 г. - URL: http://demoscope.ru/weekly/ssp/rus_nac_10.php (дата обращения: 14.03.2018). 
Начало XX века, тем более период Первой мировой войны - время известных трагических событий для всего армянского народа, которые непосредственно в геодемографическом плане обернулись очередным в многовековой истории армян кардинальным изменением их системы расселения. Геноцид 1915-1916 гг., массовая миграция последующих лет и распад Османской империи, потерявшей значительную часть своей территории, на порядок сократили демографический потенциал армянского населения Турции. В течение 15-20 лет она перестала быть главным средоточием армянского народа. И в качестве такового определилась Советская Россия, в начале середине1920-х годов уже многократно опережавшая Турцию по численности своего армянского населения (рисунок 4).

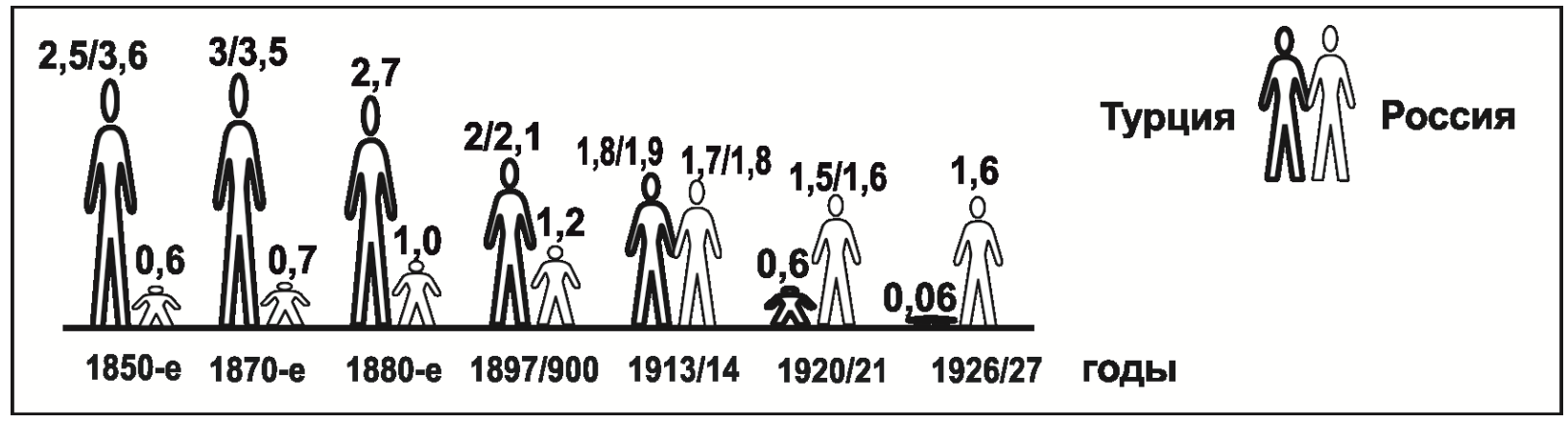

Рисунок 4. Динамика численности армянского населения в Османской Порте (Турции) и в Российской империи (СССР), 1850-е - 1920-е годы, млн ${ }^{3}$

Однако в первую очередь беженцами и мигрантами в поздней Российской империи пополнилось Закавказье; во много меньшей степени - Юг России, в пределах которого в конце XIX - начале XX века осело всего несколько десятков тысяч мигрантов. До центральной России, тем более ее зауральских регионов, эта миграционная волна практически не докатилась. И хотя общая численность российских армян в первой четверти века выросла почти втрое, перепись 1926 г. (рисунок 5) обнаружила почти ту же их географию, что и в конце XIX века. Более 95\% армян России (в современных границах РФ) по-прежнему являлись жителями ее южного макрорегиона.

Очевидным процесс пространственной децентрализации системы расселения армянского населения в пределах РСФСР становится только в 1930-е годы. К концу данного десятилетия доля его за пределами Юга увеличивается в 3 раза и превышает 20\% от общей численности. Объяснение, казалось бы, лежит на поверхности. Стремительно выросшая в период первых пятилеток и всесоюзных трудовых десантов межрегиональная миграция затягивала в свою пространственную циркуляцию и население Армении. Отчасти так и было. Число армян РСФСР за пределами ее южного макрорегиона в 1926-1939 гг. выросло в 3,5 раза (рисунок 6), однако на самом Юге их количество в это время сократилось. В абсолютных цифрах сокращение было незначительным, но с учетом имевшегося естественного прироста местного армянского населения масштабы его оттока могли достигать 15-20\% (если не 25\%) от общей численности армян южного макрорегиона.

\footnotetext{
${ }^{3}$ Картосхема составлена по данным, собранным Г.Г. Саркисяном [Армяне 2012: 81-87]. 


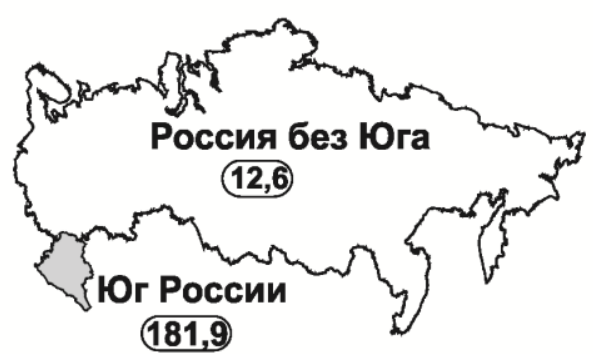

Численность армян в России (тыс. чел.)

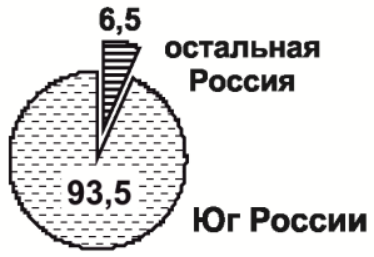

Доля в общей численности российских армян (\%)

\section{Армяне по административным территориям Юга России} Число армян (чел.)

15-25

(100-180

(.) $250-400$

(560-740

(O) $2200-$

( $5800-$

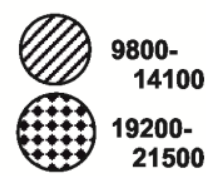

00-

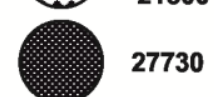

27730
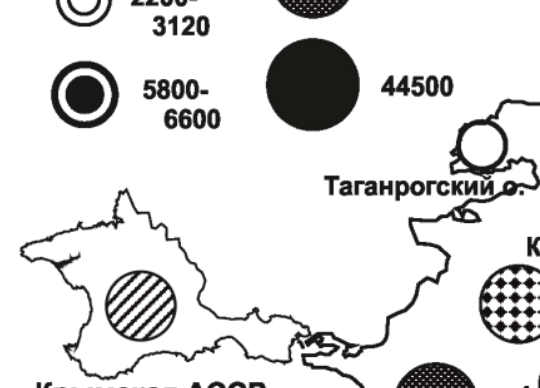

таганрогский

\section{O}

онецкий о.

Сталинград

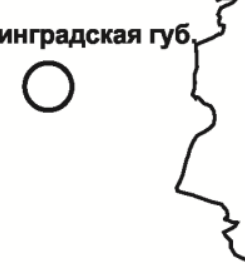

Сальский 0 .

Астраханская губ.

Крымская АССР

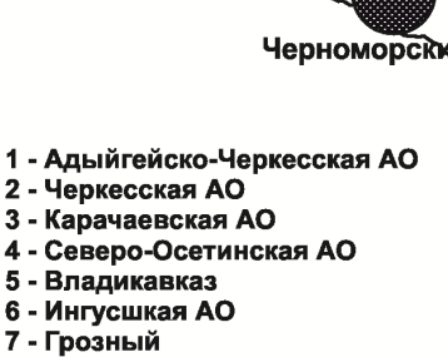

Кубанский о.

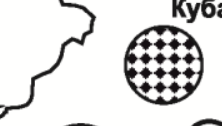

Армавирский о.
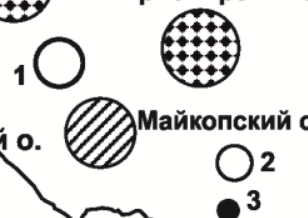

(O) Ставропольский о. Терский $о$. (O)

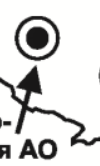
Кабардино-<smiles></smiles>

\section{(7)}




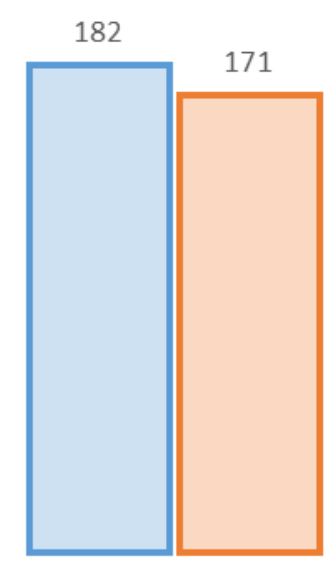

юr РСФСР

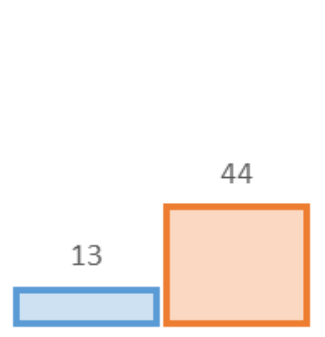

остальная РСФСР

\section{Рисунок 6. Динамика армянского населения южного макрорегиона и остальной РСФСР, 1926-1939, тыс.}

Как результат, численность армянского населения во многих российских регионах увеличивается многократно. Впрочем, даже этого роста в межвоенный период было недостаточно, чтобы новые региональные группы армян (они по-прежнему концентрировались в городах), превратились в крупные демографические средоточия, сопоставимые по размеру с ведущими городскими общинами Юга России (рисунок 7).

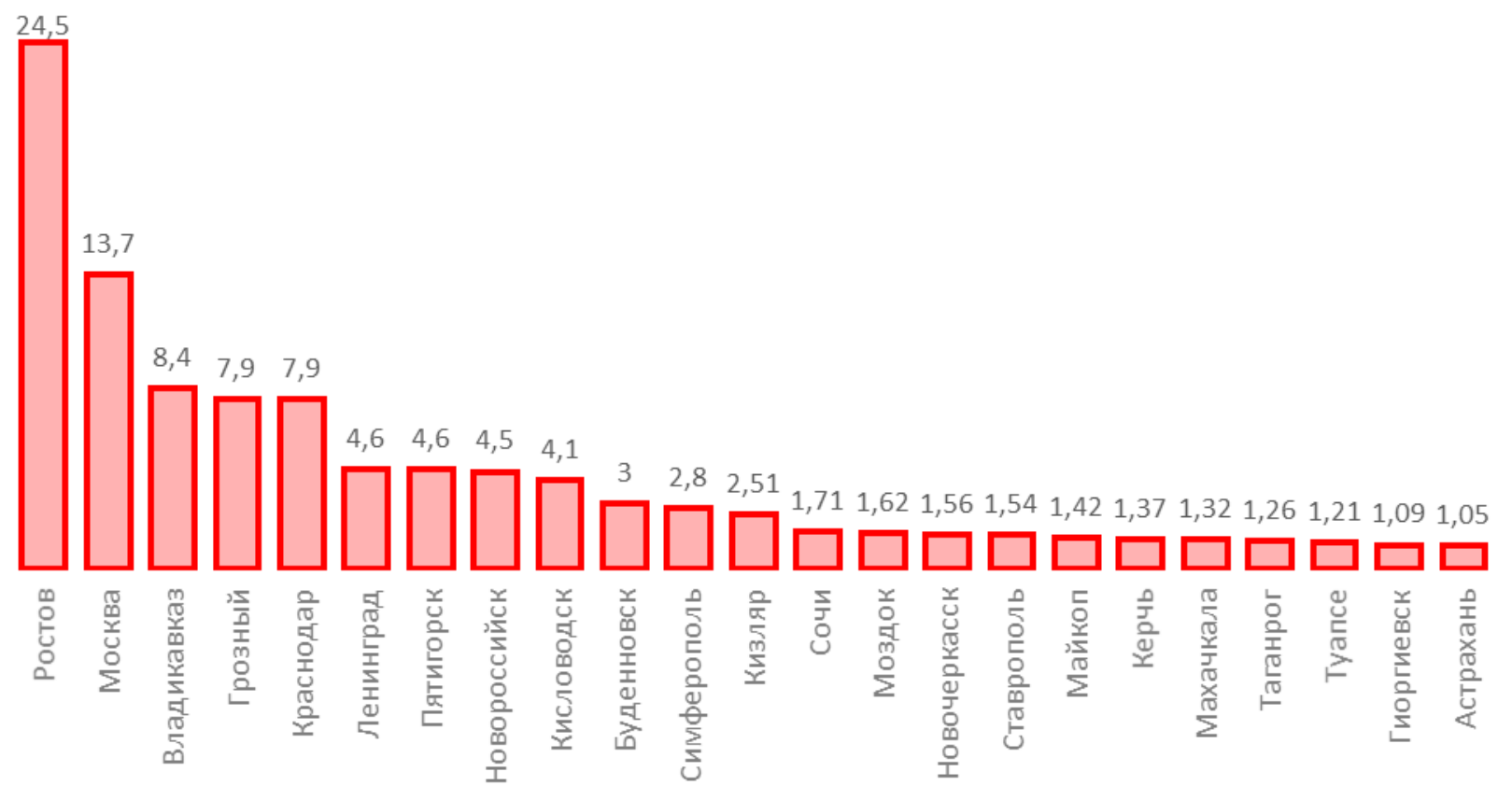

Рисунок 7. Размеры ведущих городских армянских общин РСФСР, 1939, тыс. чел.

Помимо городской формы расселения, сохраняется и другая социодемографическая особенность российских армян - значительный гендерный дисбаланс. В большинстве регионов большой России за пределами ее южных территорий армянское население в 1930е годы по-прежнему было преимущественно представлено мужчинами. 
Отечественная война самым существенным образом отразилась на геодемографической динамике армянского населения России. Но первая послевоенная перепись населения СССР была проведена только в 1959 г. Полтора послевоенных десятилетия компенсировали понесенные человеческие потери, замаскировали связанные с войной сдвиги системы расселения и, в целом, зафиксировали некоторый количественный рост армянского населения РСФСР в сравнении с довоенным периодом (с 218 тыс. человек в 1939 г. оно увеличилось до 256 тыс. на рубеже 1960-х годов).

В дальнейшем этот восходящий демографический тренд уже не прерывался. Причем параллельно росли как общины юга России, так и группы армян в других макрорегионах РСФСР. В пространственном плане этот рост был почти повсеместным. И если в 1959 г. размеры большинства региональных групп российских армян располагались в диапазоне 100-500 человек, то к концу 1980-х годов они поднялись в среднем до 1-3 тыс. (рисунки 89). Однако даже столь значительный количественный рост долгое время оказывается недостаточным условием для превращения данного растущего демографического множества в полноценную сеть территориальных общин, о чем наглядно свидетельствует гендерная структура большинства региональных групп российских армян в 1970 г. (рисунок $10)$.

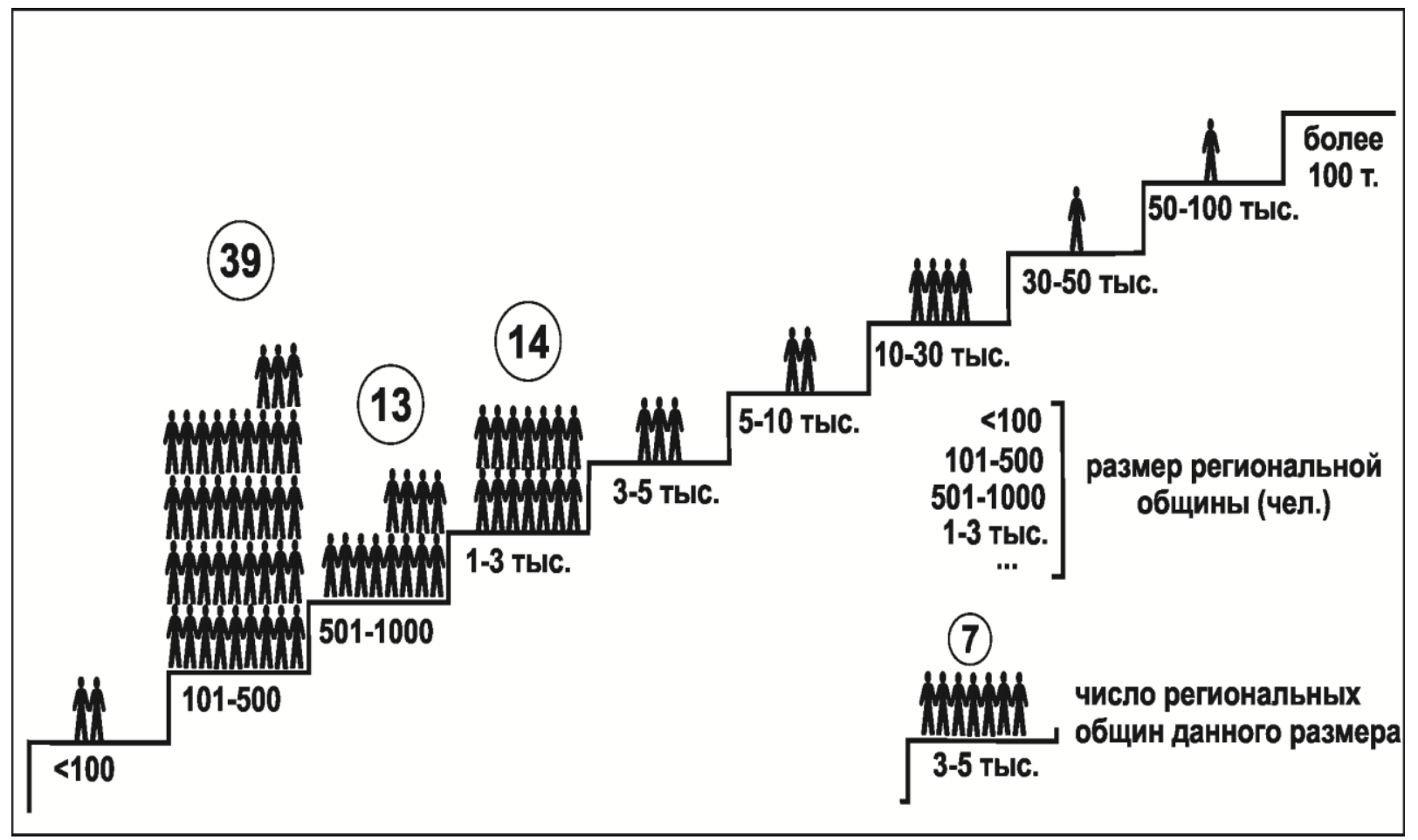

Рисунок 8. Размеры региональных групп армянского населения в РСФСР, 1959 


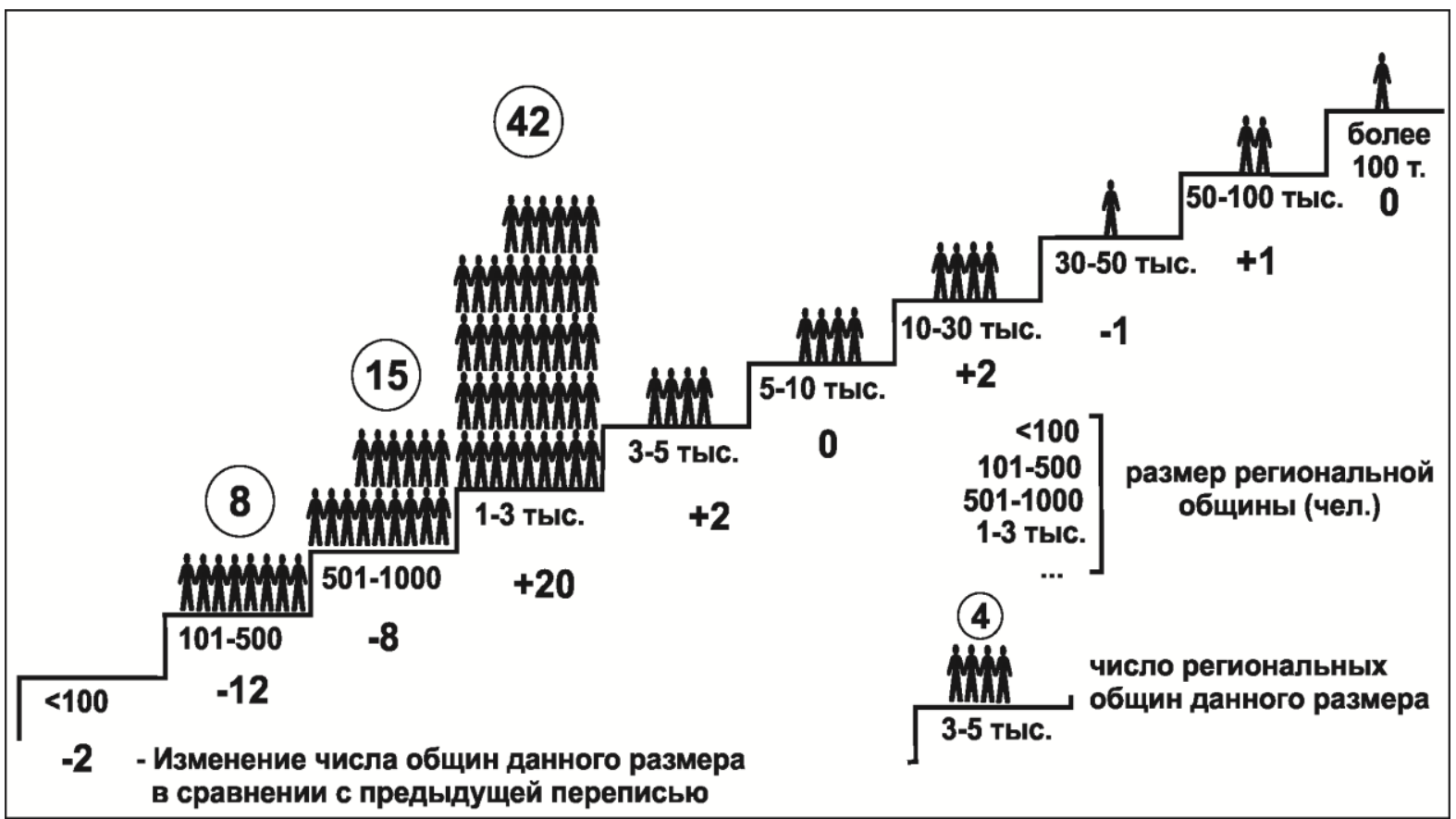

Рисунок 9. Размеры армянских региональных общин в РСФСР, 1989

\begin{tabular}{|c|c|c|c|}
\hline \multicolumn{2}{|r|}{1897} & \multicolumn{2}{|c|}{1970} \\
\hline $\begin{array}{l}\text { Число мужчин на } \\
100 \text { женщин: }\end{array}$ & $\begin{array}{l}\text { Число регионов с данным } \\
\text { гендерным соотношением }\end{array}$ & $\begin{array}{l}\text { Число мужчин на } \\
100 \text { женщин: }\end{array}$ & 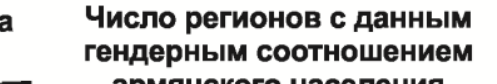 \\
\hline 2220 & армянского населения & $1000-1100$ & 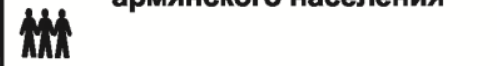 \\
\hline $1070-1290$ & Hith & $660-715$ & $x$ \\
\hline $770-970$ & Howh & $401-600$ & hombing (8) \\
\hline $530-600$ & the & $301-400$ & 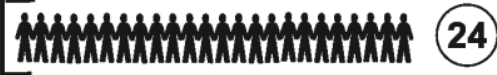 \\
\hline $300-430$ & 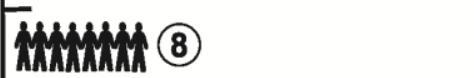 & 201-300 & 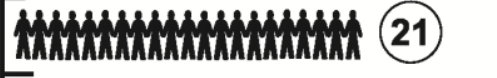 \\
\hline $220-280$ & 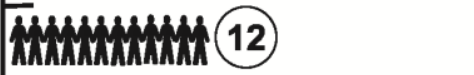 & $161-200$ & 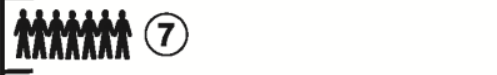 \\
\hline $140-170$ & Nerrity 8 & $131-160$ & Wh \\
\hline $110-140$ & 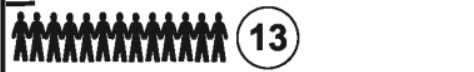 & $111-130$ & Erithe \\
\hline $100-110$ & Exith & $100-110$ & Wh \\
\hline $68-82$ & Extre & 91-99 & trikn \\
\hline
\end{tabular}

Рисунок 10. Уровень гендерной сбалансированности российских региональных групп армянского населения, 1897, 1970

В сравнении с началом XX века уровень гендерного дисбаланса мало изменился. К началу 1970-х годов в России за пределами ее южного макрорегиона по-прежнему преобладали территориальные группы армян с 2-4-кратным количественным перевесом мужчин. Иными словами, армянское население большой России, как и в межвоенный 
период, было преимущественно представлено одинокими мужчинами молодого и среднего возраста - студентами вузов и техникумов, военнослужащими, трудовыми мигрантами, разного рода командировочными специалистами. Неудивительно, что такие территориальные этнические множества очень медленно трансформировались в полноценные региональные общины.

Положение ощутимо меняется только в последнее советское десятилетие. Стремительный количественный рост миграции армян в РСФСР, связанный с трагическими событиями в Закавказье, системным кризисом, а затем и распадом Советского Союза, существенно увеличивает российские территориальные группы. В 34 регионах России численность армян в 1980-е годы выросла более чем вдвое; еще в 28 - увеличилась на 50$100 \%$. К концу советского периода в 58 российских регионах армянское население превышало тысячу человек (десятилетием раньше таких региональных групп было только 34; рисунок 11).

Эта миграционная волна в отличии от миграций предыдущих десятилетий уже не была столь отчетливо привязана к городской системе. Спешный, а иногда практически «эвакуационный», характер данного переселенческого потока определял вынужденную расселенческую неприхотливость новых мигрантов. Люди, убегавшие от войны и погромов, далеко не всегда имели материальные возможности для того, чтобы осесть в городах, жилье и проживание в которых были дороже, чем в сельской местности.

Как результат, уровень урбанизации армянского населения в 1980-е годы сократился почти в 60 российских регионах, причем в половине из них весьма ощутимо (на 10\% и более). А сокращение доли горожан означало, что уровни этнического присутствия армян в городской и сельской местности РСФСР, столь ощутимо расходившиеся еще в начале середине 1970-х годов, теперь существенно сблизились. По преимуществу вынужденный характер армянской миграции этого времени определил и серьезные сдвиги в гендерной структуре переселенцев. В отличие от стабильных 1960-1970-х годов, когда за пределы Кавказа на учебу и в поисках работы ехали в основном молодые одинокие мужчины, миграционный поток 1980-х в первую очередь формировался семьями, вынужденными оставлять место своего прежнего проживания навсегда.

Тем самым, мужской перевес в подавляющем большинстве российских территориальных групп сократился. Но главное, из территории временного пребывания (места получения образования, заработка, профессиональной реализации) регионы большой России начали превращаться для новых мигрантов в основное место жизни со всеми вытекающими последствиями, связанными с необходимостью плотно встраиваться в принявшую их социальную среду.

Планы и желания вынужденных мигрантов различались. Далеко не все приехавшие в российскую «глубинку» собирались навсегда укореняться в тех местах, куда их занесло в результате спешного отъезда из Закавказья. Однако именно то, что в этой новой среде они оказывались полными семьями, зачастую становилось центральным фактором, в конце концов определявшим их дальнейшую судьбу и существенно ускорявшим интеграцию мигрантов в принявшие их социумы. 


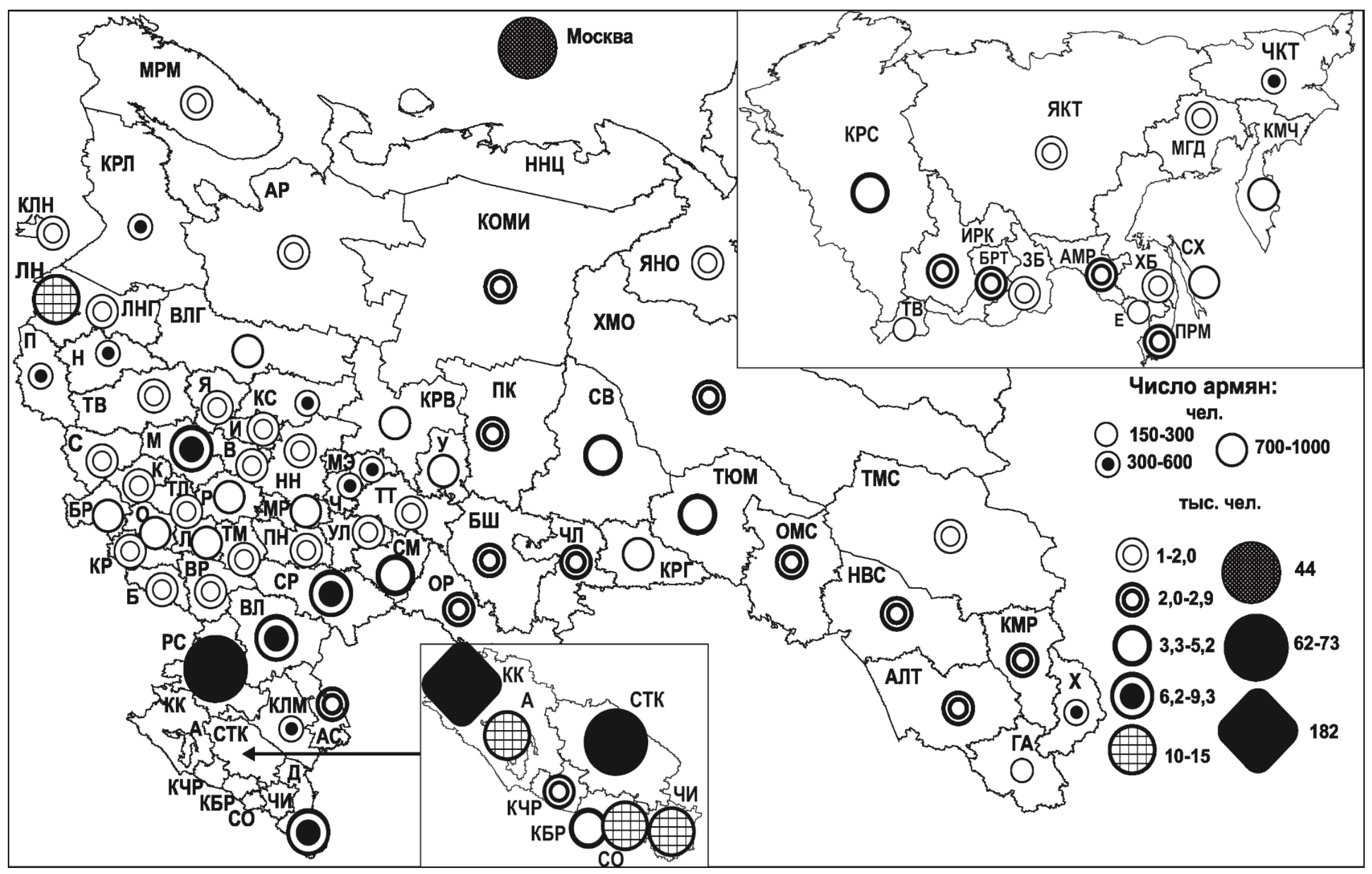

Рисунок 11. Региональные группы армянского населения в регионах РСФСР, 1989 
Таким образом, одновременно в десятках регионов России начинается стихийный процесс перехода территориальных дисперсных множеств армян в региональные общины (т.е. трансформация преимущественно мужских, городских по форме расселения разрозненных групп населения с быстро сменяемым составом в хорошо структурированные, гендерно сбалансированные сообщества с высокой долей лиц постоянного проживания). Такие сообщества в значительно большей степени были расположены ко внутренней соорганизации и взаимодействию.

Речь идет о приобретении нового качества, позволяющего считать такие территориальные группы уже не просто множествами людей одной национальности, но полноценными региональными общинами. Повторимся, отдельные элементы этого системного перехода просматриваются в социальной и геодемографической динамике российских армян уже в 1960-1970-е годы. Но резкая активизация данного процесса приходится именно на середину - вторую половину 1980-х годов, продолжившись уже в постсоветский период (в значительном числе российских регионов этот процесс полностью не завершен и в настоящее время, растянувшись, таким образом, на многие десятилетия).

Первое постсоветское десятилетие было связано с еще более впечатляющим количественным ростом армянского населения России. За 1989-2002 гг. оно увеличилось с 0,53 млн до 1,14 млн человек, позволив армянам подняться в демографическом рейтинге народов РФ сразу на восемь позиций (с 15-й на 7-ю).

Почти в трех десятках регионов РФ рост территориальных групп в 1990-е годы оказался более чем трехкратным; еще в 26 численность армян выросла в 2-3 раза. В абсолютных цифрах, как и следовало ожидать, максимальное пополнение получили южнороссийские регионы, прежде всего, все три ведущие общины Предкавказья (кубанская, ставропольская и донская), общая численность которых выросла почти на четверть миллиона человек.

Однако впервые совокупный демографический рост армянского населения других макрорегионов России оказался выше. За 1989-2002 гг. армян в РФ, за пределами ее южного макрорегиона, стало больше в три с лишним раза (их число увеличилось со 167 тыс. до 514 тыс. человек). Тем самым параллельно ощутимому расширению географии армянского народа в России произошла серьезная территориальная «перецентрировка» его системы расселения.

Даже сохранив очевидное демографическое превосходство над другими территориями, Юг России заметно снизил степень своего доминирования, заключая в своих пределах лишь немногим более половины всех российских армян (рисунок 12). Зато существенно прибавили в своих удельных показателях центральная Россия и Поволжье: совокупная доля армянских общин двух федеральных округов (Центрального и Приволжского) выросла за 1989-2002 гг. с 18,6 до 29,5\%. Увеличилась в общей структуре и доля уральских, а также сибирских территориальных групп. 


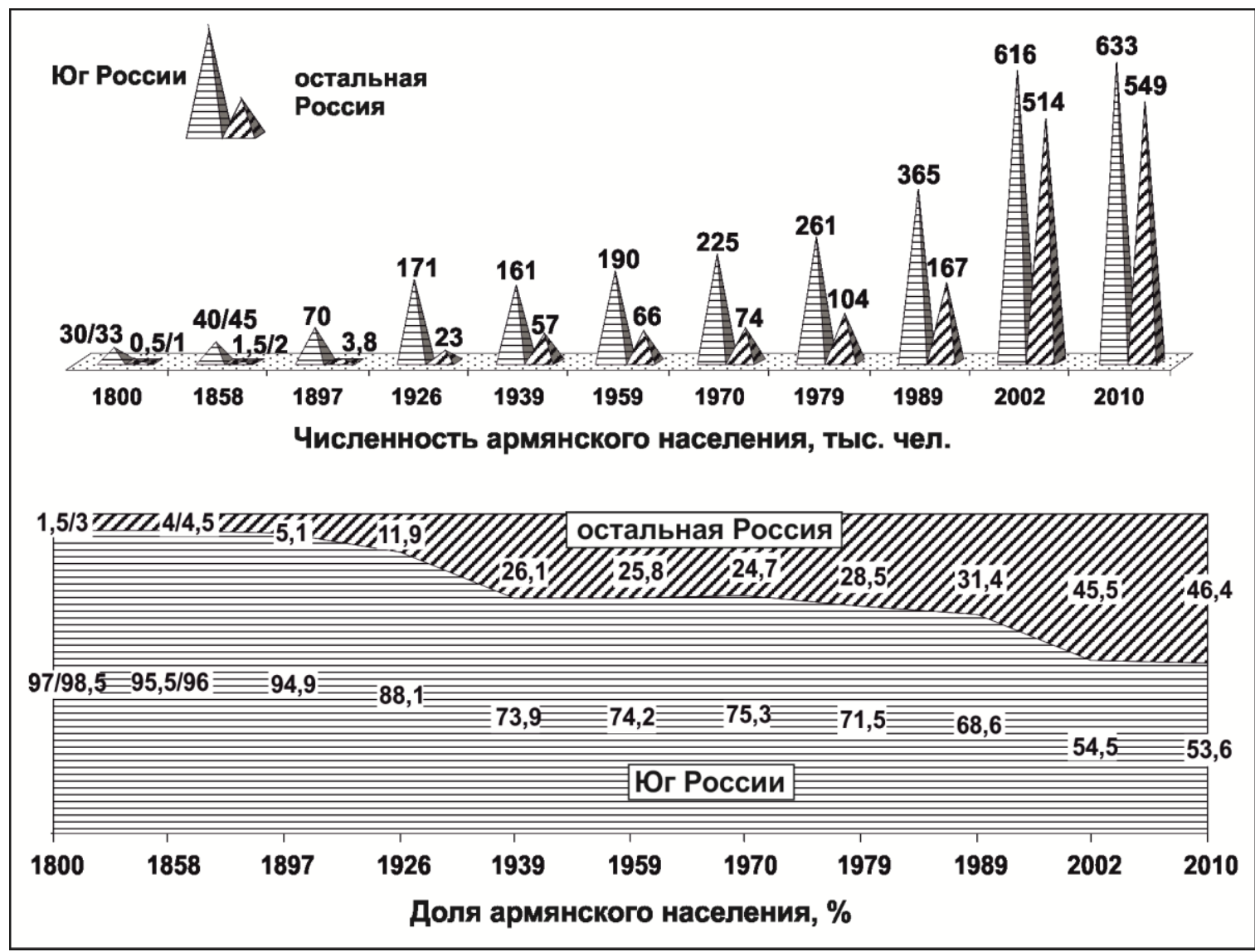

Рисунок 12. Соотношение армянского населения южного макрорегиона и остальной России, 1800-2010 4

Столь стремительный демографический рост российской диаспоры позволил самым ощутимым образом увеличить удельное представительство армян не только в сотнях городов страны, но и на обширных сельских территориях. Продолжал выправляться и гендерный баланс: основную часть потока мигрантов, расходившегося по всей российской провинции, составляли полные семьи, кардинальным образом менявшие половозрастную структуру местных территориальных групп армянского населения.

Первое десятилетие XXI века - период определенной количественной стабилизации и пространственной оптимизации российской диаспоры армян, связанной с внутри- и межрегиональным перетоком части постсоветских переселенцев. За 2002-2010 гг. число армян в РФ, согласно результатам последней российской переписи, вырастает только на 4,6\%. Однако детальный анализ их геодемографической динамики в этот период позволяет предположить, что некоторая часть представителей диаспоры последней переписью учтена не была.

\footnotetext{
4 Данные по Югу России приведены без учета армян Крыма и потому несколько отличаются от показателей на рисунках 1-2, 5.
} 


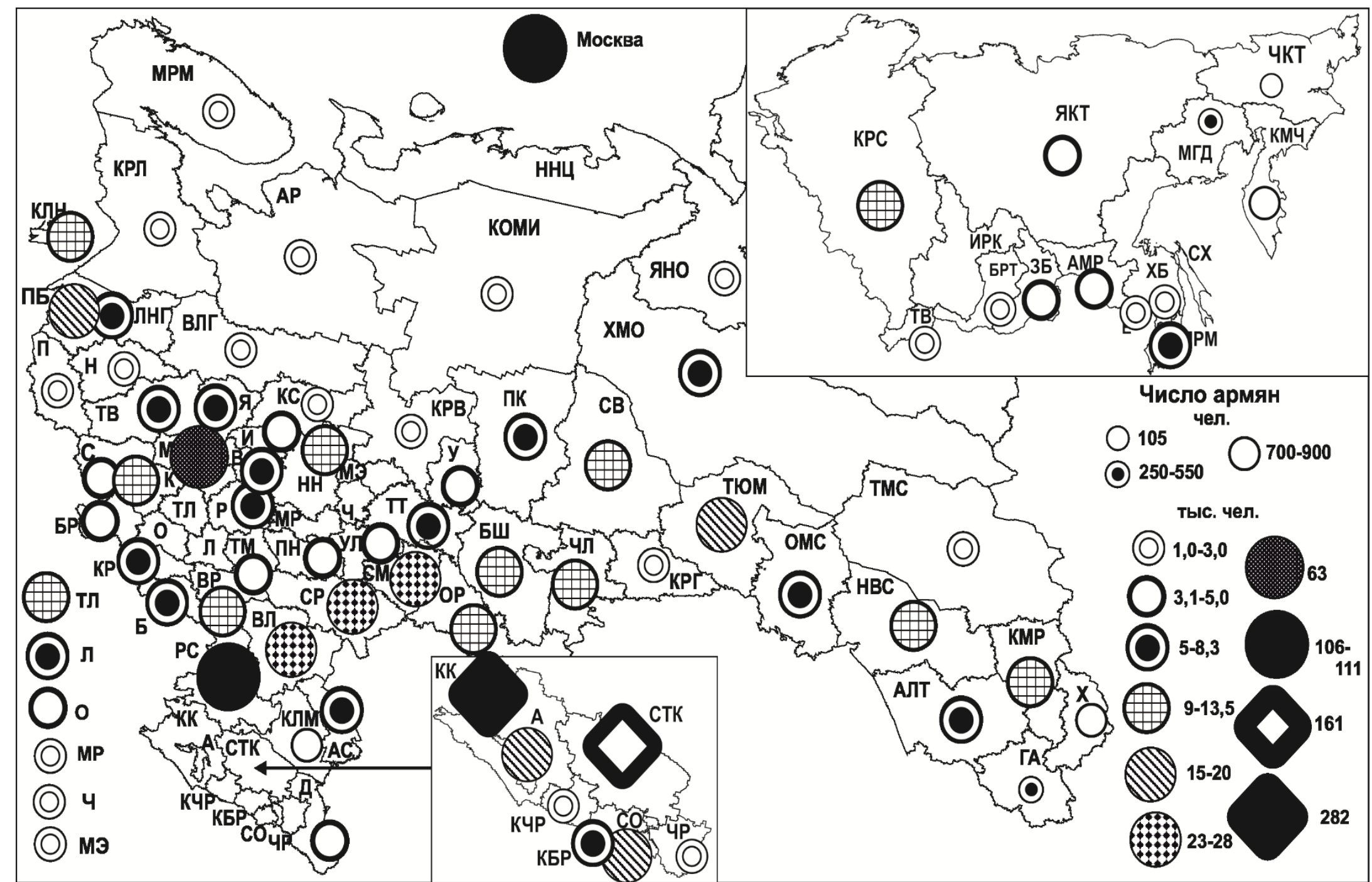

Рисунок 13. Региональные группы армянского населения в регионах России, 2010 
Согласно нашим расчетам, наиболее вероятная численность армянского населения РФ в 2010 г. могла составлять 1,35-1,45 млн (т.е. была на 15-23\% больше зафиксированного переписью). Иными словами, по своему демографическому потенциалу армяне были вполне сопоставимы с чувашами и чеченцами, занимавшими в это время соответственно 5ю и 6-ю позиции в рейтинге наиболее крупных народов России.

Впрочем, данное предположение не отменяет раннее сделанного вывода о постепенной количественной и пространственной стабилизации армянской диаспоры РФ в начале XXI века, темпы роста которой в любом случае существенно упали. 2000-е годы время внутренней оптимизации новой системы расселения армян, сложившейся в период их быстрого и стихийного демографического роста. Осваиваясь в принявших их российских регионах, переселенцы начинают искать более комфортные и приемлемые для себя центры (районы) проживания и трудовой деятельности. Происходит более или менее интенсивный меж- и внутрирегиональный переток армянского населения. Последняя перепись зафиксировала сокращение численности армян в 28 регионах РФ, а значительный рост (более чем на 20\%) - только в 14 (еще в 12 регионах армянское население выросло на $10-20 \%)$.

Очевидно, что ресурсы дальнейшего пространственного расширения системы расселения армян в пределах России если не исчерпаны, то достаточно невелики. Климатически, этнокультурно, социально-экономически наиболее приемлемые/комфортные территории страны диаспорой уже демографически освоены. И дальнейшее серьезное расширение этой этнической географии маловероятно, а все другие ее изменения (в частности, межрегиональная демографическая «перецентрировка») останутся поступательно-непрерывными процессами.

Иллюстрацией подобной «постепенности» является уже не раз упоминавшийся тренд на дальнейшую территориальную децентрализацию диаспоры, сокращение в ней удельного демографического веса южнороссийских общин. Данная тенденция сохранилась и в 2000-е годы. Однако за 2002-2010 гг. доля Юга России в общей численности российских армян снизилась менее чем на $1 \%$ (с 54,5 до 53,6\%). Три из четырех крупнейших региональных общин размером более 100 тыс. человек по-прежнему относятся к Югу России (Краснодарский и Ставропольский края, Ростовская область), как и все шесть регионов, в которых армяне составляют более $1 \%$ местного населения.

Зато новой активизацией отметился в «нулевые» другой долговременный тренд опережающий демографический рост столичной общины ${ }^{5}$. Общее число российских армян, проживающих в Москве и области, увеличилось в период между переписями со 135 тыс. до 170 тыс. (рост составил 26\% против 4,5\% у всей российской диаспоры). Симптоматичной была и другая его геодемографическая особенность. Впервые за всю историю развития московской территориальной группы на первый план вышло Подмосковье, численность армян в котором в 2000-е годы выросло на 60\% (максимальный показатель среди всех

\footnotetext{
${ }^{5}$ Которая уже в 1970-е годы, наконец, выходит на позицию крупнейшей городской общины российских армян, опередив армянское население Ростова и Нахичевани-на-Дону, занимавшее это место на протяжении почти двух столетий (данные центры были объединены в начале 1920-х годов).
} 
российских регионов). Очевидно, что речь идет о быстром формировании еще одного (следом за югом РФ) крупнейшего демографического средоточия системы расселения российских армян. И есть все основания полагать, что данный процесс будет продолжен, а значит, не только число, но и доля «столичных» армян продолжит увеличиваться в России опережающими темпами (только в 1989-2010 гг. она выросла с 10 до 14,4\%).

Параллельно в постсоветский период ощутимо вырос удельный вес армян Поволжья (с 4,9 до 9,1\%) и Центрального федерального округа (с 3,4 до 8,5\%). Тем самым, продолжалась децентрализация системы расселения российской армянской диаспоры, взаимоувязанная с демографическим ростом значительного числа ранее периферийных территориальных групп. Этот процесс был напрямую связан и с увеличением уровня представленности армян в национальной структуре своих регионов. Если в 1989 г. в РФ имелось 40 регионов, в которых доля армян была меньше $0,1 \%$ от численности местного населения, то к 2010 г. таких осталось всего два (Чеченская республика и Ингушетия).

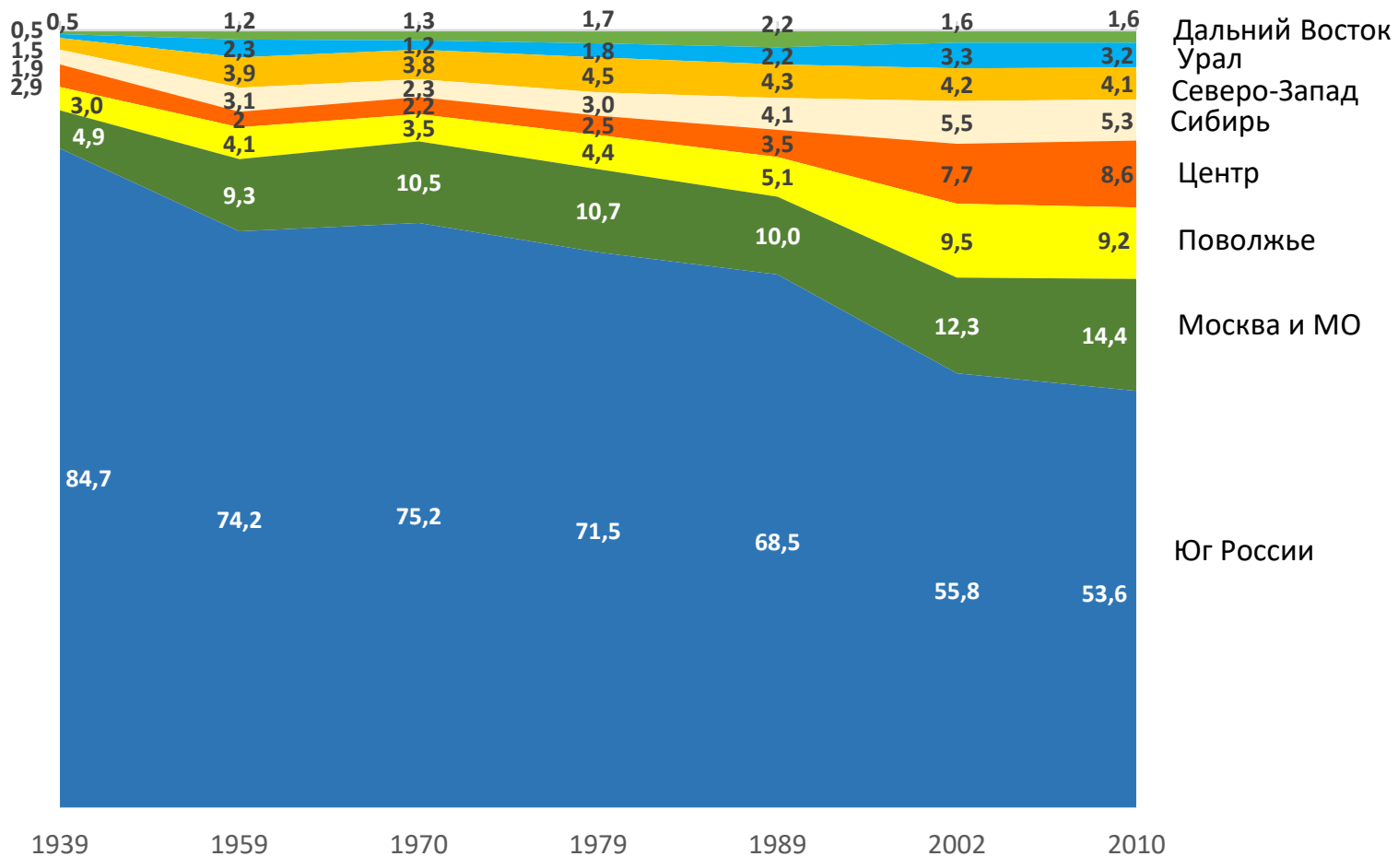

Рисунок 14. Доля макрорегионов в размещении армянского населения России, 1939-2010, \%

Но более значимым для комплексного укоренения территориальных групп армян в принимающие региональные социумы являлись их внутренняя оптимизация и, прежде всего, дальнейшее сокращение гендерного дисбаланса. Если в 1989 г. в 37 российских регионах в структуре местного армянского населения количественный перевес мужчин над женщинами был более чем двукратным, то в 2010 г. таких регионов осталось только 3 (рисунок 15). При этом с 8 до 13 возросло число общин со сбалансированной гендерной структурой (отношение полов 1:1-1,2) - свидетельство постепенного повышения системной устойчивости территориальных групп армянского населения России. 


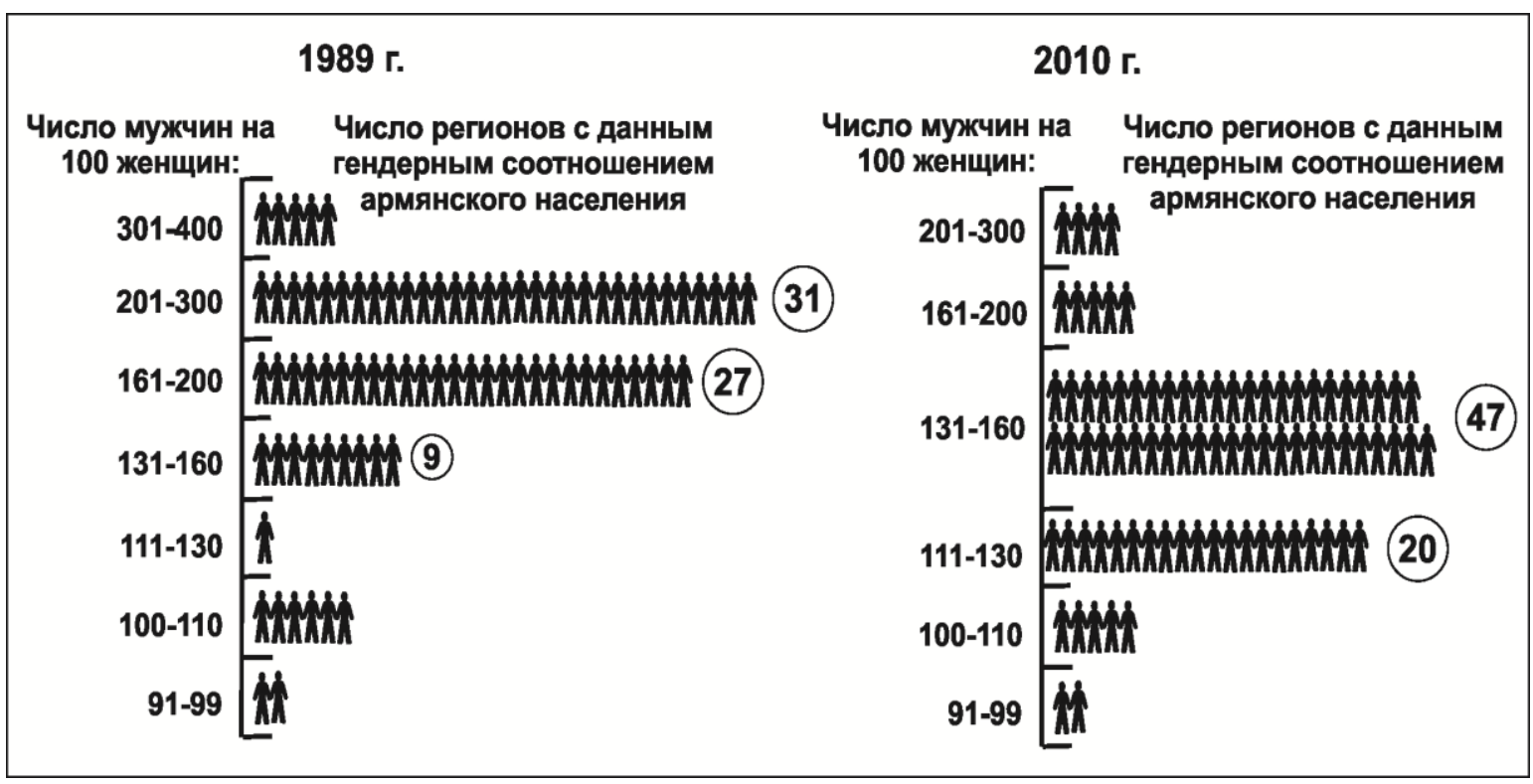

Рисунок 15. Уровень гендерной сбалансированности российских региональных групп армянского населения, 1989-2010

Существенно выросшая в постсоветский период сельская миграция снизила общий уровень урбанизации армян России. В 2010 г. он составлял 69\% и был ниже, чем у всего населения РФ (73,7\%). Но показательно, что в 70 субъектах РФ доля горожан у представителей местных армянских общин превосходила общерегиональные показатели урбанизированности населения. Что неудивительно, учитывая демографический «бум» многих армянских городских общин, в первую очередь, относящихся к административным столицам регионов. За 1989-2010 гг. число таких общин размером более тысячи человек в России выросло 2,4 раза (с 48 до 115). Причем большинство из них появилось вне пределов южного макрорегиона. И впервые в истории российской диаспоры общее число армянских городских общин в большой России превзошло их количество на Юге страны (61 против 53 ; рисунок 16).

\begin{tabular}{|c|c|c|c|c|c|c|c|c|}
\hline \multirow[b]{2}{*}{1897 r. } & \multicolumn{3}{|c|}{$\begin{array}{l}\text { число армянских городских } \\
\text { общин данного размера }\end{array}$} & & $\begin{array}{l}\text { города южного маІ } \\
\text { города остальной }\end{array}$ & $\begin{array}{l}\text { кррорегиона } \\
\text { России }\end{array}$ & \multicolumn{2}{|c|}{ Общее число общин } \\
\hline & Dececes & $\infty$ & & - & & & & 10 \\
\hline 1939 r. & $+t$ & $\infty$ & & $\infty$ & $\infty$ & & & (23) \\
\hline 1989 r. & & $\infty 6000$ & & 000 & Oeces & $\infty$ & & (48) \\
\hline 2010 r. 8 & 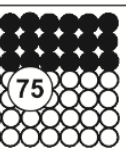 & $\begin{array}{c}18 \\
180000 \\
000\end{array}$ & 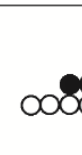 & 5080 & ecesceso & $\infty$ & 0 & 115 \\
\hline$T$ & 3 тыс. & 3-5 тыс. & $\begin{array}{c}5-11 \\
\text { ра3! }\end{array}$ & $\begin{array}{l}\text { тыс. } \\
\text { мерыс }\end{array}$ & $\begin{array}{l}10-30 \text { тыс. } \\
\text { общин }\end{array}$ & 30-50 тыс. & Т более 50 & bc \\
\hline
\end{tabular}

Рисунок 16. Динамика числа крупных (более тысячи человек) городских общин российских армян, 1897-2010 


\section{Выводы}

Итак, «новая» история армянской диаспоры в России, начавшаяся в петербургский период, не просто продолжается уже на протяжении трех веков, но в последние десятилетия вышла на более высокий системный уровень, связанный не только со стремительно выросшим демографическим потенциалом (рисунок 17) и широкой географией, но и значительно более высоким уровнем внутренней организации большинства eе региональных средоточий. Начало XXI века российская диаспора встретила на системном подъеме, фиксируемом во всех сферах ее деятельности и закладывающем прочный фундамент для положительной геодемографической динамики на всю обозримую перспективу

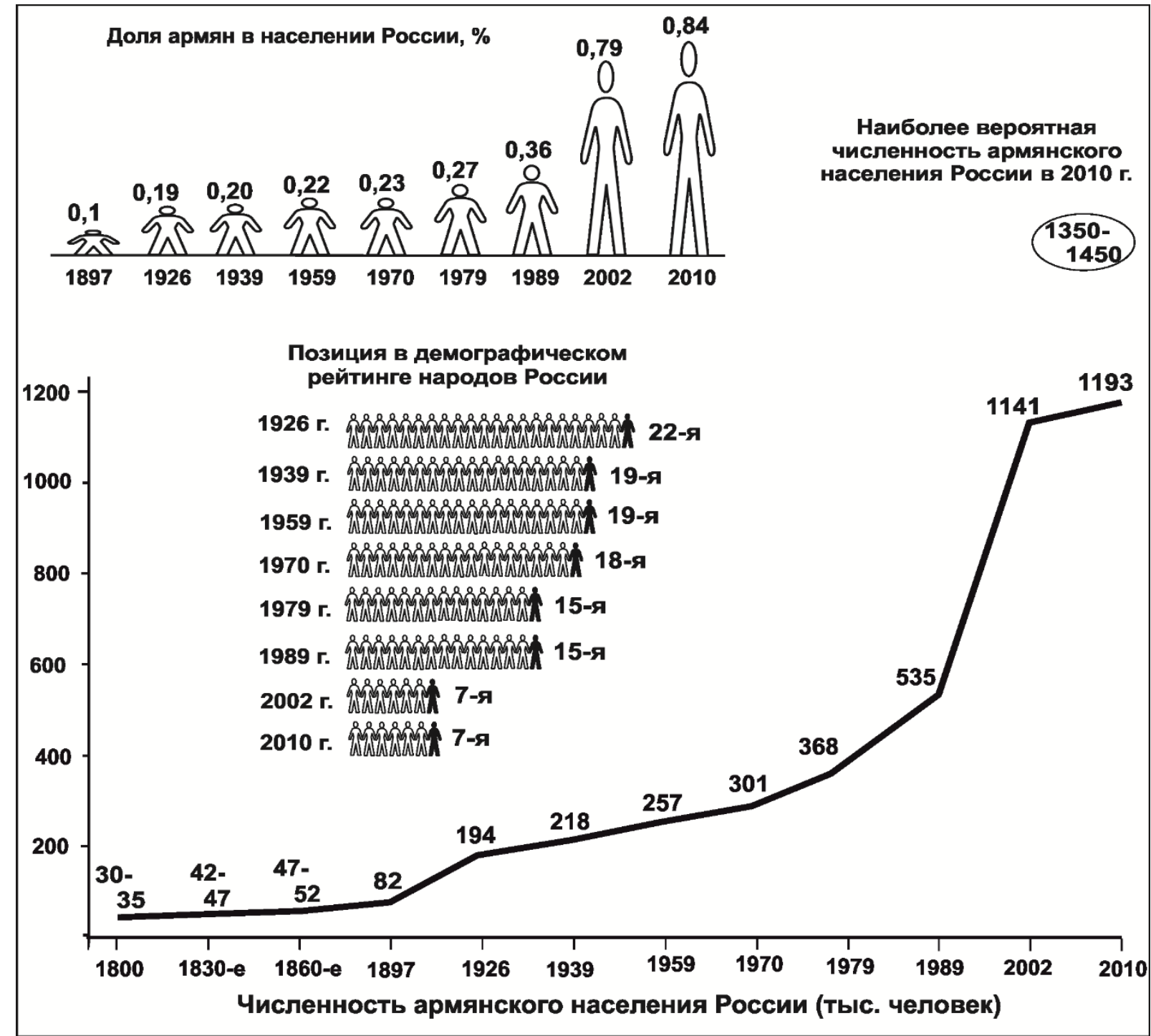

Рисунок 17. Динамика армянского населения России, 1800-2010

Проведенное исследование позволяет в первом приближении выделить в геодемографической истории российских армян три крупных периода, различающихся как по общей их численности в России, широте географии, так и по другим центральным социодемографическим характеристикам (в том числе форме расселения, уровню урбанизации, гендерному соотношению; рисунок 18). 


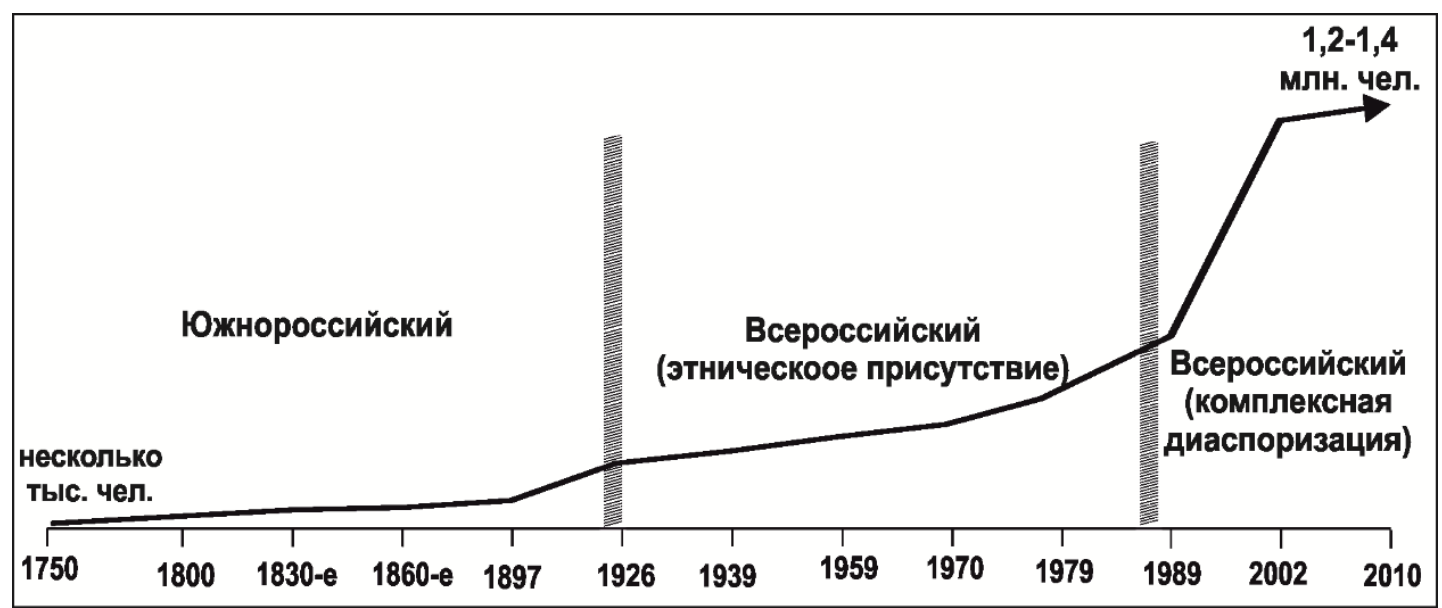

Рисунок 18. Крупные периоды исторической этапности геодемографической динамики армянской диаспоры России

Первый из этих периодов можно определить как «южнороссийский». Его начало относится ко второй трети XVIII века и связано с возникновением на юге России ряда крупных региональных общин/колоний. Данный период оказался наиболее длительным, растянувшись до второй четверти XX века. На всем его протяжении подавляющая часть армянского населения России (в еe современных пространственных контурах) концентрировалась в пределах южного макрорегиона, а еще точней - в степном Предкавказье (нижний Дон, Кубань, Ставрополье). Во всей остальной России присутствие армян в это время остается минимальным (если не принимать в расчет двух столичных общин, впрочем, тоже весьма ограниченных по своему размеру).

Тем самым, к центральным характеристикам данного периода можно отнести:

- максимальную концентрацию (95\% и более общей численности) российских армян в границах степного Предкавказья и других территорий Юга России;

- поступательный количественный рост и постепенное расширение географии армян в пределах данного макрорегиона;

- активное участие местных общин в процессе региональной урбанизации, в хозяйственной и культурной жизни южного макрорегиона; высокий уровень урбанизации большинства территориальных групп Юга и сбалансированную гендерную структуру;

- $\quad$ минимальное присутствие армян за пределами Юга России, представленных в других макрорегионах страны «одиночками» или локальными группами в несколько человек, состоящими преимущественно из мужчин, сосредоточенных в крупных городах.

Второй период геодемографической динамики российских армян можно условно обозначить как этап «всероссийского этнического присутствия». Данный этап почти полностью совместился с советской эпохой, закончившись в середине 1980-х годов. Основными его социогеодемографическими особенностями являются:

- постепенный рост числа региональных групп армянского населения за пределами Юга России и расширение их общероссийской географии; 
- $\quad$ рост совокупного демографического потенциала армян большой России (и удельного веса в структуре местного населения) при сохранении общей количественной доминанты общин южного макрорегиона;

- высокий уровень урбанизированности большинства российских региональных групп;

- неустойчивый состав (постоянная «ротация» наличного населения) и значительный (зачастую многократный) перевес мужчин в территориальных группах армян за пределами Юга России - факторы, определявшие низкий уровень укорененности данных групп в основных сферах жизнедеятельности региональных социумов;

- низкий уровень внутренней соорганизованности, слабое развитие групповых (общинных) социальных структур в большинстве российских региональных групп, не представляющих в данное время диаспор/общин в полном смысле данного понятия.

Третий период начинается в середине-второй половине 1980-х годов и может быть определен как период «всероссийской комплексной диаспоризации» армянского населения РФ. Он характеризуется быстрым количественным ростом и пространственным расширением диаспоры; выправлением гендерного дисбаланса (сокращением мужского перевеса), активным социально-экономическим и социокультурным укоренением армян в десятках российских регионов.

К основным социодемографическим особенностям данного периода можно отнести:

- стремительный демографический рост и быстрое пространственное расширение большинства региональных групп армянского населения РФ;

- опережающие темпы геодемографической динамики армян большой России, нарастающую децентрализацию системы расселения российской диаспоры и ощутимое сокращение демографической доли общин южного макрорегиона;

- существенное снижение уровня мужского количественного доминирования в большинстве региональных групп; значительный рост в территориальных общинах доли семейного и постоянного населения;

- опережающий рост во многих российских регионах численности и удельного веса сельских армян, позволивший существенно повысить показатель их этнического присутствия в российской сельской «глубинке»;

- активное формирование общинных социальных структур и институтов; трансформацию многих дисперсных территориальных групп армянского населения в хорошо структурированные региональные общины;

- комплексную интеграцию общин в жизнедеятельные циклы принимающих территориальных социумов, их общественно-политическую, экономическую и культурную жизнь;

- быстрый рост совокупного социально-экономического потенциала территориальных общин; расширение присутствия их представителей во всех статусных профессиональных сообществах и корпоративных иерархиях своих регионов.

Этап активной диаспоризации российских армян не завершен и, судя по всему, потребует еще значительного времени. Однако данная системная трансформация далеко не напрямую связана с демографической динамикой общины, которая зависит от трех 
факторов: естественного прироста (убыли), направления и активности миграционных процессов; наконец, от масштаба ассимиляции.

Учитывая существующие параметры естественной динамики армянского населения РФ (в зависимости от региона - простое воспроизводство или минимальный прирост), а также стабильное миграционное пополнение и ограниченные масштабы ассимиляционных потерь, есть все основания прогнозировать дальнейший количественный рост армянской диаспоры в России.

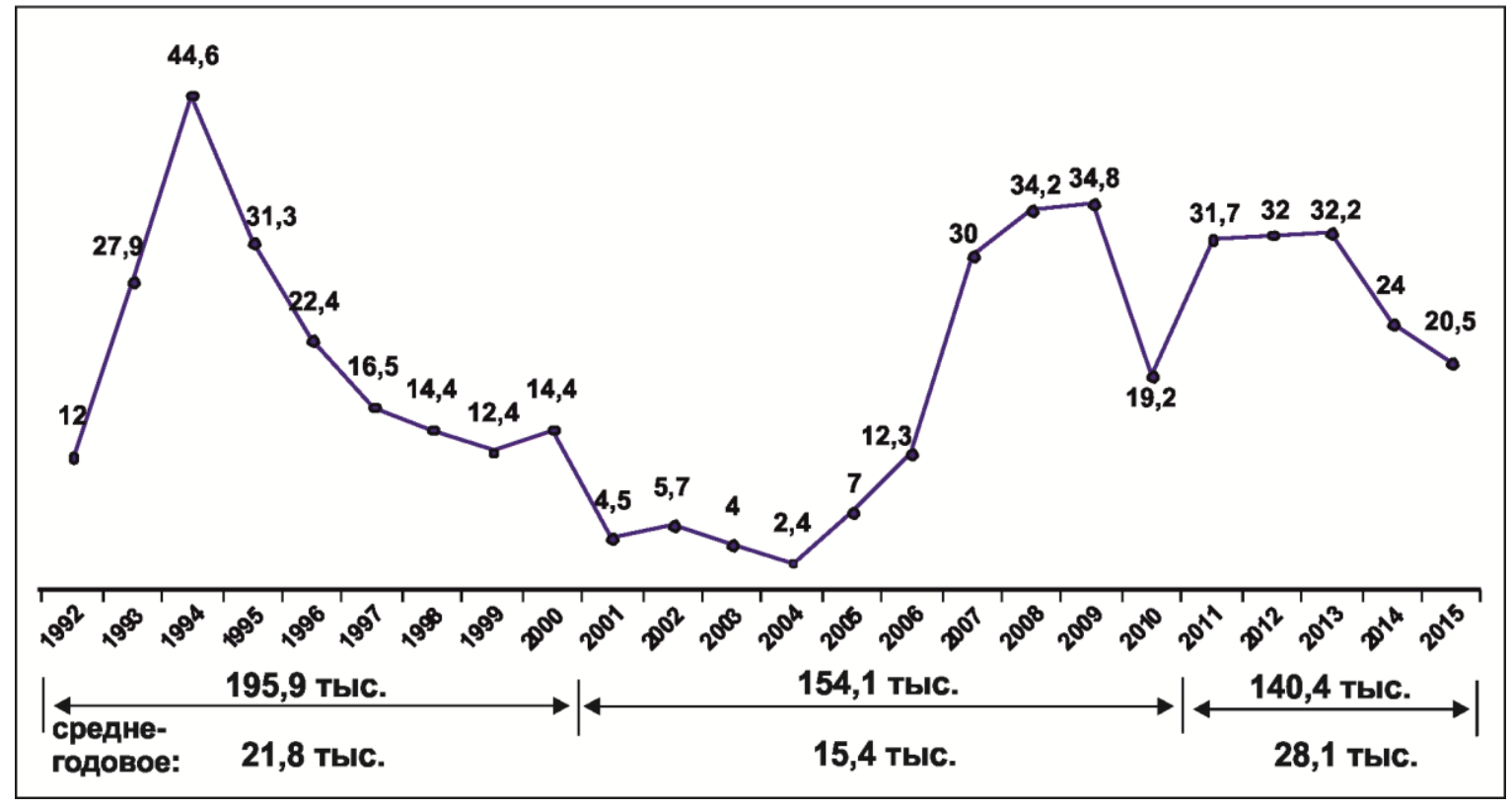

\section{Рисунок 19. Чистый приток населения (сальдо миграции) из Армении в Россию, 1992-2015, тыс. ${ }^{6}$}

Даже в «официальном» демографическом рейтинге народов РФ армяне в текущем десятилетии с большой вероятностью поднимутся на две позиции и войдут в пятерку крупнейших национальных сообществ России (рисунок 20). Это произойдет, даже если скрытая демографическая компонента армянской общины во время ближайших двух переписей не выйдет из тени. Если же эта компонента будет учтена, то российские армяне, число которых к 2030 г. может составить 1,85-1,95 млн, становятся реальными претендентами на место в тройке крупнейших народов России следом за русскими и татарами. В любом случае речь будет идти об очень сближенном демографическом показателе с чеченцами и башкирами, но прежде всего с первыми из них.

\footnotetext{
${ }^{6}$ Для составления графика использовались данные из [Демографический ежегодник...2001, 2006, 2012, 2017].
} 


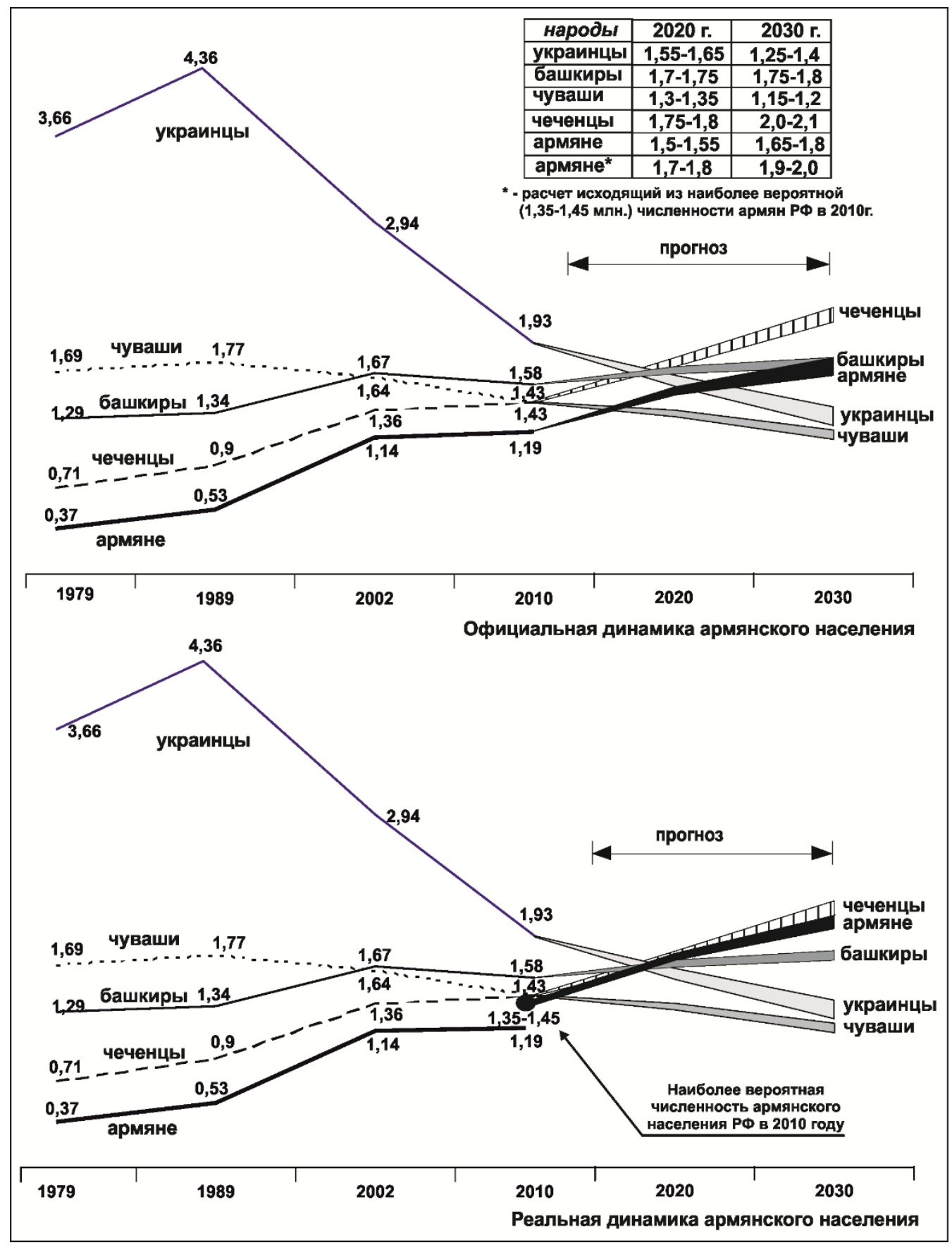

Рисунок 20. Наиболее вероятные варианты количественной динамики ряда ведущих народов РФ в ближайшей (2020 г.) и среднесрочной (2030 г.) перспективе, млн

При этом в пространственном отношении ожидать заметных сдвигов едва ли стоит - география центральных мест российской диаспоры в целом сформирована. Ведущим ее средоточием на всю обозримую перспективу останется юг России (степное Предкавказье), а также присоединившийся к нему в последние десятилетия столичный регион (Москва и область), на которые в настоящее время в сумме приходится около $60 \%$ российских армян (рисунок 21). 


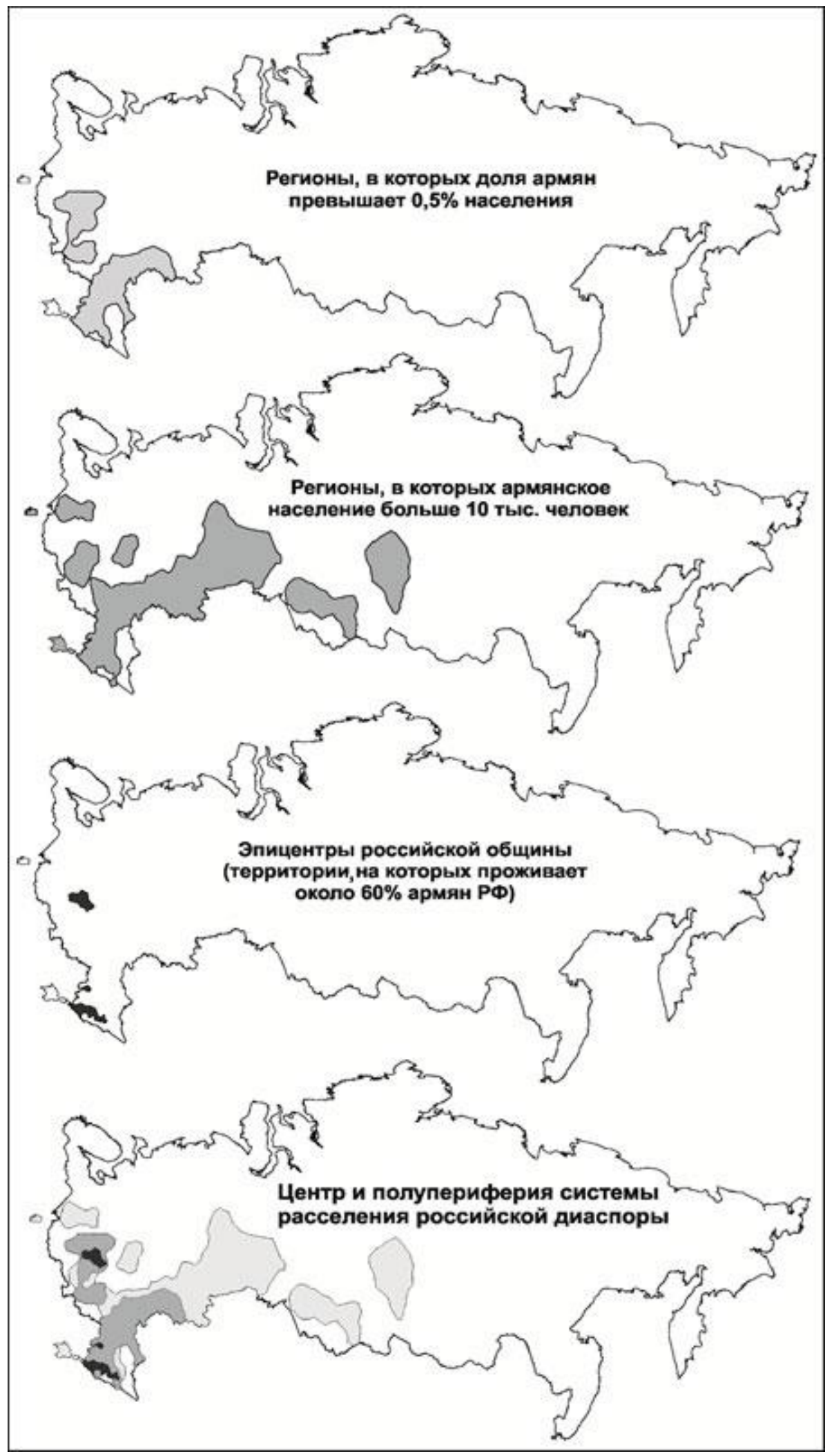

Рисунок 21. Центральные зоны системы расселения армян России 


\section{ЛИТЕРАТУРА}

Аваков П.А. (2012). Армяне на Дону в XVII-XVIII вв. (до 1779 г.) // Армяне Юга России: история, культура, общее будущее. Ростов-на-Дону: Издательство УИФЦ РАН: 120125.

Аганесова Д.В., И.А Суздальцева. (2007). Армянские общины Дагестана в XVIII - начале ХІХ вв. Махачкала. 244 с.

Акопян В.3. (2005). Краткий очерк по истории армянских поселений на Юге России. Пятигорск: ПГЛУ. URL: http://armeniansite.ru/istoriya-armyanskikh-poselenij-rossii/4istoriya-armyanskikh-poselenij-na-yuge-rossii.html (дата обращения 17.03.2018).

Аракелян Г.С. (1984). Черкесогаи (историко-этнографическое исследование) // Кавказ и Византия. Вып. 4. Ереван: 43-130.

Армяне (2012). Народы и культуры / Отв. ред. Л.М. Варданян, Г.С. Сарксян, А.Е. Тер-Саркисянц. М.: Наука. 648 с.

Волкова Н.Г. (1966). О расселении армян на Северном Кавказе до начала XX века // Историко-филологический журнал. 3: 259-264.

Демографический ежегодник России 2001 (2001). М.: Госкомстат: 336-339.

Демографический ежегодник России 2006 (2006). М.: Росстат: 469-470.

Демографический ежегодник России 2012 (2012). М.: Росстат: 452-455.

Демографический ежегодник России 2017 (2017). М.: Росстат: 210-212.

Кабузан В.М. (1990). Народы России в XVIII веке. Численность и этнический состав. М.: Наука. 256 с.

Кабузан В.М. (1996). Население Северного Кавказа в XIX-XX веках. СПб.: Блиц. 224 с.

Тер-Саркисянц А.Е. (1998). Армяне - история и этнокультурные традиции. М.: Восточная литература. 397 с.

Тер-Саркисянц А.Е. (2005). История и культура армянского народа с древнейших времен до начала XIX века. М.: Восточная литература. 686 с. 


\title{
ARMENIANS OF RUSSIA: GEO-DEMOGRAPHIC TRENDS OF THE PAST, MODERN REALITIES AND PROSPECTS
}

\section{$\underline{\text { SERGEIY SUSHCHIY }}$}

\begin{abstract}
The article analyzes the quantitative growth, spatial dynamics, gender structure and form of resettlement of the Armenian population of Russia in the 18th-20th centuries. The demographic correlation of the largest regional communities at different stages of their development are studied, and the main historical periods of the geo-demographic dynamics of the Armenians of Russia determined.

The first stage can be designated as "South Russian" (second third of the 18th century - 1920s). At this time, the overwhelming majority of the Armenian population of Russia was concentrated within the southern macro-region. In the second stage (mid-1920s - first half of the 1980s), Armenians resettled almost throughout the entire territory of the RSFSR, but represented internally weakly connected ethnic groups. The third period (the second half of the 1980s - the present) is associated with the transformation of these groups into developed regional communities.

Three centuries of quantitative growth allowed Armenians to become one of the largest ethnic groups in the Russian Federation by the beginning of the 21st century. In the medium term (by 2030), with a favorable scenario of demographic dynamics, Armenians will be able to take the third position in the demographic rating of the peoples of Russia (after the Russians and Tatars).
\end{abstract}

Key words: geo-demographic dynamics, Armenian population of Russia, regional diasporas, migration processes, resettlement system, gender balance.

SERGEIY SUSHCHIY (SS7707@mail.ru), SOUTHERn SCIENTIFIC CENTER OF THE RUSSIAN ACADEMY OF SCIENCES, RUSSIA.

THE ARTICLE IS PERFORMED WITHIN THE FRAMEWORK OF THE PROJECT OF THE RUSSIAN FOUNDATION FOR BASIC RESEARCH "THE ARMENIAN COMMUNITY OF THE DON IN THE NEWEST PERIOD: HISTORY, INSTITUTIONS, IDENTITY" (18-59-05004).

DATE RECEIVED : MAY 2018.

\section{REFERENCES}

Aganesova D.V., I.A. Suzdal'tseva (2007). Armyanskie obshchiny Dagestana v XVIII - nachale XIX vv. [Armenian communities of Dagestan in the XVIII - early XIX centuries]. Makhachkala. 244 p.

Akopyan V.Z. (2005). Kratkiy ocherk po istorii armyanskikh poseleniy na Yuge Rossii [A short essay on the history of Armenian settlements in the South of Russia]. Pyatigorsk: PGLU. URL: http://armeniansite.ru/istoriya-armyanskikh-poselenij-rossii/4-istoriya-armyanskikhposelenij-na-yuge-rossii.html (accessed: 18.02.2018).

Arakelyan G.S. (1984). Cherkesogai (istoriko-etnograficheskoe issledovanie) [Cherkessogai (historical and ethnographic study)] // Kavkaz i Vizantiya [Caucasus and Byzantium]. Issue. 4. Yerevan: 43-130.

Armyane [The Armenians] (2012). Narody i kul'tury [Peoples and cultures] / L.M. Vardanyan, G.S. Sarksyan, A.Ye. Ter-Sarkisyants, eds. Moscow: Nauka. 648 p.

Avakov P.A. (2012). Armyane na Donu v XVII-XVIII vv. (do 1779 g.) [Armenians on the Don in the XVII-XVIII centuries (before 1779)] // Armyane Yuga Rossii: istoriya, kul'tura, obshchee budushchee [Armenians of the South of Russia: history, culture, common future]. Rostov-on-Don: Izdatel'stvo YUNTS RAN: 120-125. 
Demograficheskiy ezhegodnik Rossii 2001 [Demographic yearbook of Russia 2001] (2001). Moscow: Goskomstat: 336-339.

Demograficheskiy ezhegodnik Rossii 2006 [Demographic yearbook of Russia 2006] (2006). Moscow: Goskomstat: 469-470.

Demograficheskiy ezhegodnik Rossii 2012 [Demographic yearbook of Russia 2012] (2012). Moscow: Goskomstat: 452-455.

Demograficheskiy ezhegodnik Rossii 2017 [Demographic yearbook of Russia 2017] (2017). Moscow: Goskomstat: 210-212.

Kabuzan V.M. (1990). Narody Rossii v XVIII veke. Chislennost' i etnicheskiy sostav [Peoples of Russia in the XVIII century. Number and ethnic composition]. Moscow: Nauka. 256 p.

Kabuzan V.M. (1996). Naselenie Severnogo Kavkaza v XIX-XX vekakh [The population of the North Caucasus in the XIX-XX centuries]. St. Petersburg: Blits. 224 p.

Ter-Sarkisyants A.Ye. (1998). Armyane - istoriya i etnokul'turnye traditsii [Armenians - history and ethno-cultural traditions]. Moscow: Vostochnaya literatura: $397 \mathrm{p}$.

Ter-Sarkisyants A.Ye. (2005). Istoriya i kul'tura armyanskogo naroda s drevneyshikh vremen do nachala XIX veka [History and culture of the Armenian people from ancient times to the beginning of the nineteenth century]. Moscow: Vostochnaya literatura. $686 \mathrm{p}$.

Volkova N.G. (1966). O rasselenii armyan na Severnom Kavkaze do nachala XX veka [On the resettlement of Armenians in the North Caucasus before the beginning of the XX century] // Istoriko-filologicheskiy zhurnal [Historical and Philological Journal]. 3: 259-264. 